\title{
The Promise and Perils of Crowdfunding: Between Corporate Finance and Consumer Contracts
}

\author{
John Armour* \\ Luca Enriques ${ }^{* *}$
}

\begin{abstract}
'Crowdfunding' — raising capital through large numbers of small contributions - is a burgeoning phenomenon, spurred by the internet's capacity to reduce communication costs. Its still-evolving status is reflected in diversity of contracting practices: for example, 'equity' crowdfunders invest in shares, whereas 'reward' crowdfunders get advance units of product. These practices occupy a hinterland between existing regimes of securities law and consumer contract law, in which their treatment is not consistent. For example, consumer protection law in the UK (but not the US) imposes mandatory terms that impede risk-sharing in reward crowdfunding, whereas US (but not UK) securities law mandates expensive disclosures that hinder equity crowdfunding. This article offers a normative roadmap for the regulation of crowdfunding. We suggest that while crowdfunding poses real risks for funders, neither the classical regulatory techniques of securities or consumer law provide an effective response. At the same time, a review of rapidly-developing mechanisms in crowdfunding markets suggests they offer the potential to provide meaningful protection for funders. In light of this, an initially permissive regulatory approach, open to learning from market developments yet with a credible threat of intervention should markets fail to protect consumers, is justified.
\end{abstract}

Keywords: consumer contracts, consumer finance, crowdfunding, distance selling, securities law, startup finance

\footnotetext{
* Hogan Lovells Professor of Law and Finance, University of Oxford; Fellow, ECGI.

** Allen \& Overy Professor of Corporate Law, University of Oxford; Fellow, ECGI.

We are grateful for feedback received at presentations at an Oxford Business Law Workshop; the University of Auckland Law Faculty; Universidad Carlos III de Madrid Department of Business; the ETH-NYU Law \& Banking/Finance Conference 2015 in Zurich; Munich University's Center for Advanced Studies; the NUS-ETH Law and Banking Colloquium 2016 in Singapore; the University of Hong Kong; the AEDE $7^{\text {th }}$ Conference at Catolica Global Law School, Lisbon; Durham Law School and the European Commission (DG-FISMA). We thank in particular Doug Cumming, Horst Eidenmüller, Lars Hornuf, Lin Lin, Geoff Miller, and Tjio Hans and two anonymous referees for helpful comments. Martin Bengtzen provided excellent research assistance. The usual disclaimers apply. All URLs were last accessed 29 May 2017.
} 


\section{A Introduction}

Start-up firms — with untried products, and often untested founders - frequently find it difficult to obtain finance. ${ }^{1}$ This difficulty has arguably been exacerbated by constriction in bank lending since the financial crisis. ${ }^{2}$ Because start-up firms are disproportionately associated with innovation and job creation, ${ }^{3}$ the possibility of a 'funding gap' for start-up firms is a significant concern for policymakers. ${ }^{4}$

In the last few years, a new source of finance for start-ups, known as 'crowdfunding' ('CF'), has become widely available. As the name implies, this involves raising capital from a large number of individuals, each of whom typically contributes a small sum. The internet has lowered the costs of raising funds in this way, by facilitating the dissemination of information about small projects. Use of CF has grown exponentially. Industry statistics estimate a total of

\footnotetext{
${ }^{1}$ See BIS, 'SME Access to External Finance', BIS Economics Paper No 16, January 2012; A. Freeman, Challenging Myths About the Funding of Small Businesses: Finance for Growth (London: Demos, 2013); National Audit Office, BIS and HM Treasury, Report by the Comptroller and Auditor General: Improving Access to Finance for Small and Medium-Sized Enterprises, HC 734, November 2013, 13-15; British Business Bank, 'Analysis of the UK Smaller Business Growth Loans Market', Research Report, March 2015; cf R. Brown and S. Lee, Funding Issues Confronting High Growth SMEs in the UK (Edinburgh: ICAS, 2014).

${ }^{2}$ See eg I. McCafferty, 'UK Business Finance Since the Crisis-Moving to a New Normal?', speech given at Bloomberg, London, 20 October 2015.

${ }^{3}$ See eg B.H. Hall, 'Innovation and Productivity', NBER Working Paper No 17178 (2011); L. Kogan et al, 'Technological Innovation, Resource Allocation, and Growth’, NBER Working Paper No 17769 (2012); National Audit Office, BIS and HM Treasury, Report by the Comptroller and Auditor General: Improving Access to Finance for Small and Medium-Sized Enterprises, HC 734, November 2013, 13; BIS, 'SMEs: The Key Enablers of Business Success and the Economic Rationale for Government Intervention', BIS Analysis Paper No 2, December 2013; J. Edler and J. Fagerberg, 'Innovation policy: what, why, and how' (2017) 33 Ox Rep Econ Pol 2, 9-10.

${ }^{4}$ For details of recent policy initiatives, see BIS and HM Treasury, '2010 to 2015 Government Policy: Business Enterprise’, Policy Paper, May 2015, available at https://www.gov.uk/government/publications/2010-to-2015government-policy-business-enterprise.
} 
\$34 billion was raised worldwide using crowdfunding in 2015, having grown thirteen-fold over just three years. ${ }^{5}$ This is just over a sixth of the amount raised worldwide through initial public offerings ('IPOs') on equity markets in the same year. ${ }^{6}$

While the availability of CF is clearly good news for entrepreneurs, its merits for those providing the funding are less certain. Because funders typically invest only small sums in projects, CF may appeal to consumers, that is, unsophisticated individuals. However, consumers have limited capacity to assess the prospects of a business, and are prone to making investment decisions subject to biases and herd behaviour. In addition to losses to funders, this can cause finance to be misallocated to inferior business projects. These risks raise important questions for regulators.

In this article, we sketch out a normative roadmap for the regulation of CF in relation to business start-ups. This is a highly salient enquiry. In the UK, the Financial Conduct Authority ('FCA') has recently conducted its third review of CF regulation in as many years. ${ }^{7}$ In the US, the Securities and Exchange Commission ('SEC') regulations for retail CF came into force in May 2016 pursuant to the JOBS Act of 2012; ${ }^{8}$ their operation is being carefully

\footnotetext{
${ }^{5}$ Massolution, Crowdfunding Industry 2015 Report (2016).

${ }^{6} \mathrm{EY}$, EY Global IPO Trends 2015 4Q, 4 (2016).

${ }^{7}$ FCA, Interim Feedback to the Call for Input to the Post-Implementation Review of the FCA's Crowdfunding Rules, FS16/13 (2016). See also FCA, The FCA's Regulatory Approach to Crowdfunding over the Internet, and the Promotion of Non-Readily Realisable Securities by Other Media, PS14/4 (2014).

${ }^{8}$ SEC, 'Crowdfunding: Final Rule' (2015) 80 Federal Register 71388 (17 CFR Parts 200, 226, 232, 239, 240, 249, 269 and 274).
} 
studied. Meanwhile, the European Commission is actively seeking to promote CF as part of the Capital Markets Union action plan. ${ }^{9}$

We begin by considering the use of CF and the characteristics of typical CF contracts. One type of CF contract - the 'reward' model, in which funders are rewarded with units of product—offers both firms and funders the promise of reducing uncertainty by generating new information about consumer demand. By using reward CF, founders capture synergies between their product and capital markets. Rather than raise capital and aggregate information about likely success as a by-product (through the price mechanism), they tap the product market, thus directly testing demand, and raise capital as a by-product.

In contrast, with ‘equity’ CF, where funders buy shares, their valuations are based on estimates of others' future consumption of the product and the venture's profitability, about which they have no special expertise. There is consequently a real peril that consumers (whom hereinafter we refer to as 'retail investors' when they invest in equity CF) will simply 'herd' into backing projects that early adopters have previously found attractive, which can lead to misallocation of capital.

We then review the regulation of CF in the UK (which largely reflects the implementation of EU law) and the US. Because CF is a novel practice, regulatory policy has tended, to some degree, to take the form of the application of existing frameworks designed with other contexts in mind. This has led to inconsistent, and in places misconceived, regulatory treatment.

\footnotetext{
${ }^{9}$ See European Commission, Action Plan on Building a Capital Markets Union, COM(2015) 468 final, 30 September 2015, 7; European Commission, Crowdfunding in the EU Capital Markets Union, SWD(2016) 154 final, 3 May 2016.
} 
Reward CF binds together a start-up firm's financial and product markets. The involvement of the product market means that the practice appears to be subject, in the UK, to the regime established by EU consumer protection rules, mandating amongst other things that consumers have an option to cancel the transaction and reclaim their money. This, we argue, fails to take account of funders' dual function as product consumers and financiers, in the latter aspect of which they bear risk associated with the product's completion. In contrast, few mandatory terms are imposed on consumer contracts in the US. This gives parties greater freedom to design reward CF arrangements. While reward CF is virtually non-existent in the UK, it has flourished in the US.

Equity CF involves issuing securities to investors, and for that reason is formally within the domain of 'securities law'. A central plank of securities law is mandatory disclosure, the compliance costs of which are often prohibitive for small firms. Despite the reduction of these costs in the US through a special regime for equity CF, with effect from May 2016, they still seem too high to foster the development of equity CF in that country. In contrast, equity CF has flourished in the UK, where there is an exemption from disclosure obligations under the Prospectus Directive for small offerings. In our analysis, the way equity CF markets operate is sufficiently different from traditional securities market contexts that the justifications for mandating disclosure in those other market contexts do not carry across.

The structure of the problems of CF are common to many consumer finance transactions. However, evidence-based regulatory solutions in consumer finance tend to be context-specific, and poorly-crafted intervention can easily make things worse rather than better. At this early stage of the market's development, we consequently advocate a permissive regulatory regime. This allows the promise of reward CF to be fulfilled, and offers the opportunity for the development of market solutions in respect of equity CF. In the penultimate section, we review the range of market mechanisms that have been deployed in the UK and 
other jurisdictions to overcome the contracting problems inherent in equity CF. We suggest that these hold out promise, and that an initially permissive regulatory approach, open to learning from market developments yet with a credible threat of intervention should markets fail to protect funders, is justified. At the outset, it should be emphasised that as the CF industry is in its infancy, our analysis and conclusions must be regarded as preliminary.

\section{A Crowdfunding for start-ups}

\section{B Challenges of start-up financing}

Most business start-ups fail, so funding a start-up is a risky endeavour. There is no market for the firm's product — indeed, in most cases there is not even (yet) a product—and so profitability forecasts are at best guesstimates of future production costs and market size. These factors greatly intensify the core problems of any business financing arrangement-namely, uncertainty, information asymmetry, and the risk of opportunism. ${ }^{10}$ Most founders begin by investing their savings, making use of personal credit facilities, and tapping family and friends for funds. ${ }^{11}$ For founders who have exhausted such 'personal' finance, raising outside finance is a considerable challenge. Start-ups generally do not generate steady cash flows to pay interest and-beyond re-mortgaging the founder's family home-lack liquid assets to offer as

\footnotetext{
${ }^{10}$ See generally R.J. Gilson, 'Locating Innovation: The Endogeneity of Technology, Organizational Structure, and Financial Contracting’ (2010) 110 Colum L Rev 885, 901.

${ }^{11}$ See eg A.M. Robb and D.T. Robinson, 'The Capital Structure Decisions of New Firms' (2014) 27 Rev Fin Stud 153.
} 
security. ${ }^{12}$ This makes them unattractive candidates for corporate debt financing, which constrains the most obvious source of funds for most small businesses, namely bank lending. ${ }^{13}$

Another well-known source of finance for start-ups is from venture capitalists ('VCs') and 'business angels', whose investment model is designed to accommodate the particular challenges of start-up financing. ${ }^{14}$ These investors manage the high risk of failure by diversifying their investments across a portfolio, being very selective in which firms they invest, and using specialist expertise to assess the quality of the entrepreneurial team and their project. They take control rights—often disproportionate to their investment—and use these to enhance the quality of decision-making and mitigate the potential for opportunism by the entrepreneur. ${ }^{15}$ However, such expertise is in short supply, and the investment model requires geographic proximity for the investor to be able to participate actively in decision-making. ${ }^{16}$ Consequently, venture capitalists tend to be based in areas where there are large 'clusters' of

${ }^{12}$ On home remortgage finance, see M.C. Schmalz, D.A. Sraer and D. Thesmar, 'Housing Collateral and Entrepreneurship', NBER Working Paper 19680 (2013).

${ }^{13}$ A.N. Berger and G.F. Udell, 'The Economics of Small Business Finance: The Roles of Private Equity and Debt Markets in the Financial Growth Cycle’ (1998) 22 J Bank \& Fin 613; R.E. Carpenter and B.C. Petersen, 'Capital Market Imperfections, High-Tech Investment and New Equity Financing’ (2002) 112 Economic Journal F54; P. Aghion, S. Bond, A. Klemm and I. Martinescu, 'Technology and Financial Structure: Are Innovative Firms Different?' (2004) 2 Journal of the European Economic Association 277.

${ }^{14}$ See generally P.A. Gompers and J. Lerner, The Venture Capital Cycle (Cambridge, MA: MIT Press, 1999$) ;$. Armour and L. Enriques, 'Financing Disruption', working paper, Oxford University (2016). Business angels are wealthy individuals with prior entrepreneurial experience who now invest in other projects: see eg S. Prowse, ‘Angel Investors and the Market for Angel Investments’ (1998) 22 J Bank \& Fin 785.

${ }^{15}$ W.A. Sahlman, 'The Structure and Governance of Venture Capital Organizations' (1990) 27 J Fin Econ 473; S.N. Kaplan and P. Strömberg, 'Financial Contracting Theory Meets the Real World: An Empirical Analysis of Venture Capital Contracts’ (2003) 70 Rev Fin Stud 281.

${ }^{16}$ J. Lerner, 'Venture Capitalists and the Oversight of Private Firms’ (1995) 50 J Fin 301; M.A. Zook, 'Grounded Capital: Venture Financing and the Geography of the Internet Industry, 1994-2000’ (2002) 2 J Ec Geog 151. 
new firms, typically near a source of technological innovation such as a university. ${ }^{17}$ But for an entrepreneur not living in, or able to relocate to, the vicinity of a venture capitalist, this source of finance is unlikely to be available.

No such geographic proximity is necessary for fundraising through stock markets. Unlike venture capitalists, stock market investors are generally passive, and many do not have any specialist expertise in selecting investments. Rather than making assessments themselves, they rely on securities law and the reputation of underwriters to weed out 'lemons', and the market's ability to aggregate information to ensure the price at which securities are offered is appropriate. ${ }^{18}$ However, raising capital by making a public offer involves significant fixed costs, in part associated with securities law compliance. For example, respondents to the European Commission's recent consultation on the Prospectus Directive estimated the cost of producing an IPO prospectus on a range averaging between just under $€ 1 \mathrm{~m}$ (minimum) to just over $€ 2.3 m$ (maximum). ${ }^{19}$ This puts capital-raising from regulated markets far beyond the reach of start-ups.

Against this background of apparent funding constraints for start-ups, crowdfunding offers the promise of meeting some part of entrepreneurs' unmet demand for outside finance.

\footnotetext{
${ }^{17}$ See R.L. Florida and M. Kenney, 'Venture Capital, High Technology and Regional Development’ (1988) 22 Regional Studies 33; A. Saxenian, Regional Advantage: Culture and Competition in Silicon Valley and Route 128 (Cambridge, MA: Harvard UP, 1994); R. Martin, P. Sunley and D. Turner, 'Taking Risks in Regions: The Geographical Anatomy of Europe’s Emerging Venture Capital Market’ (2002) 2 J Ec Geog 121.

${ }^{18}$ See generally J. Armour et al, Principles of Financial Regulation (Oxford: OUP, 2016), Chs 5-6.

${ }^{19}$ European Commission, Published Results: Consultation on the Review of the Prospectus Directive, available at http://ec.europa.eu/eusurvey/publication/prospectus-directive-2015?language=en. See also European Commission, Consultation Document: Review of the Prospectus Directive, February 2015 (2015), 4-6.
} 


\section{B Types of crowdfunding contract}

Crowdfunding is the aggregation of many individuals' small direct investments in a project. There is of course nothing new about this in principle. ${ }^{20}$ What is different today, however, is the scale of activity, which is driven by the use of technology to lower communication costs. Where in the past geography would have placed a constraint on the success of this kind of fundraising, ${ }^{21}$ the internet means that a great deal of information can now be conveyed to potential funders wherever they are located. ${ }^{22}$

CF bundles together multiple investment contracts written in parallel between individual investors and the entrepreneur. These contracts are typically on terms offered to the investors by the entrepreneur with the assistance of a 'platform', a web-based service that establishes a marketplace of CF offerings. ${ }^{23} \mathrm{CF}$ came to prominence initially as a technique for raising funds for charitable or public-interest projects, for which funders (donors) were promised no returns other than the satisfaction of knowing the project would be pursued. Significant amounts of money continue to be raised as such 'donation CF', but it is outside our current focus on funding for business start-ups.

\footnotetext{
${ }^{20}$ See eg N. Scholz, The Relevance of Crowdfunding (Wiesbaden, Springer Gabler: 2015), 7: the funding via patrons' donations of Mozart's and Beethoven's concerts and new music compositions and the funding by small donations from the American and French people of the Statue of Liberty are well known ante literam examples of CF.

${ }^{21}$ See eg J. Franks, C. Mayer and S. Rossi, ‘Ownership: Evolution and Regulation’ (2009) 22 Review of Financial Studies 4009, 4041-4044 (geographic proximity traditionally important for private investors in UK firms).

${ }^{22}$ A. Agrawal, C. Catalini and A. Goldfarb, 'Crowdfunding: Geography, Social Networks, and the Timing of Investment Decisions’ (2015) 24 Journal of Economics Management \& Strategy 253.

${ }^{23}$ The same contract terms are offered to all investors in a particular offer, and so we describe and analyse here the properties of the 'contract' in the singular.
} 
Two types of CF contract are particularly significant for funding business start-ups: 'reward' CF and 'equity' CF (also known as 'crowdinvesting'). ${ }^{24}$ Reward CF involves the promise of some type of valuable non-financial return on investment. With a start-up, the most common reward promised consists of one or more units of the firm's proposed product. ${ }^{25}$ Reward CF thus combines access to product and capital markets. In contrast, with equity CF, investors buy shares in start-up businesses. Table 1 sets out the amounts of funds raised using these two forms of CF in the 2012-15 period. As a comparator, Table 1 also shows funds invested in the form of seed and early-stage venture capital finance during the same period. As can be seen, the use of both types of CF has grown rapidly. In relation to the UK, equity CF has grown particularly strongly, to outstrip all UK seed and early-stage VC investment, while reward CF appears to have grown less rapidly. ${ }^{26}$

\footnotetext{
${ }^{24}$ On the terminology, see eg Massolution, Crowdfunding Industry Report 2014 (2015), 40-45; D. Cumming and L. Hornuf (eds), The Economics of Crowdfunding: Startups, Portals and Investor Behavior (London: Palgrave Macmillan, forthcoming).

${ }^{25}$ In some cases, 'rewards' may be rather more symbolic (eg 'a signed thank you from the founder'), meaning that the funding arrangement is essentially donative. We take the distinguishing feature of 'reward' from 'donative' CF to be the presence of a valuable reward.

${ }^{26}$ Data on reward CF by UK firms may be less reliable than for other forms of CF, though: while UK equity CF founders and peer-to-peer lenders can be expected to take advantage of the many successful UK platforms, which in turn the Cambridge University Centre for Alternative Finance/NESTA reports obtain their data from, the most popular reward CF platforms, such as Indiegogo and Kickstarter, are global and, at least until recently, have operated only from the US. That explains why the UK Alternative Finance Industry Reports specify that data for reward CF by UK firms are estimated 'through manual and theoretical sampling'. See eg Nesta and Cambridge Centre for Alternative Finance, The Rise of Future Finance: The UK Alternative Finance Benchmarking Report (2013), 6.
} 
Table 1: Aggregate funds invested ( $£ \mathrm{~m})$ by financial contract type, 2012-15

\begin{tabular}{|r|r|r|r|r|r|r||r|r|}
\hline Year & \multicolumn{2}{|c|}{ Total CF } & \multicolumn{2}{c|}{ Reward CF } & \multicolumn{2}{c||}{ Equity CF } & \multicolumn{2}{|c|}{ Seed/Early stage VC } \\
\hline & Global & \multicolumn{1}{|c|}{ UK } & \multicolumn{1}{c|}{ Global } & \multicolumn{1}{c|}{ UK } & \multicolumn{1}{c|}{ Global } & \multicolumn{1}{c|}{ UK } & Global & \multicolumn{1}{c|}{ UK } \\
\hline 2012 & 2,070 & 267 & 300 & 4 & 91 & 4 & 19,500 & 219 \\
\hline 2013 & 4,677 & 666 & 557 & 21 & 304 & 28 & 22,100 & 142 \\
\hline 2014 & 12,421 & 1,740 & 1,020 & 26 & 854 & 84 & 39,400 & 108 \\
\hline 2015 & 26,377 & 3,200 & 2,055 & 42 & 1,969 & 245 & 56,500 & 225 \\
\hline
\end{tabular}

Notes: Data for Global CF activity are from Massolution Crowdfunding Industry Reports; Data for UK CF activity are from Cambridge University Centre for Alternative Finance/NESTA UK Alternative Finance Industry Reports. UK equity CF data exclude real estate investments. Data for UK VC finance are from BVCA, Reports on Investment Activity; Data for Global VC finance are estimated from KPMG, Venture Pulse.

A third form of CF used for business is 'loan' CF (also known as 'crowdlending' or 'peer-to-business lending'). As the name suggests, this involves (retail) funders advancing credit to businesses, usually with the aid of credit scores produced by the platform. It too has grown very rapidly as a form of small business finance, in part because of the contraction of ordinary bank lending — for which it is a close substitute-since the financial crisis. ${ }^{27}$ As discussed, however, debt financing is unsuitable for firms without hard assets, ${ }^{28}$ which is borne out by the fact that loan CF tends to be sought by established small businesses, as opposed to start-ups. ${ }^{29}$ We consequently do not focus on loan CF in this article. ${ }^{30}$

\footnotetext{
${ }^{27}$ See eg McCafferty, n 2 above.

${ }^{28}$ n 13 above.

${ }^{29}$ See T.L. Mach, C.M. Carter, and C.R. Slattery, 'Peer-to-Peer Lending to Small Businesses', Working Paper, Federal Reserve (2014) (describing patterns of borrowing from Lending Club, a leading US loan crowdfunding platform). That said, the common practice using the founder's personal credit for seed finance (see nn 11-12 above and text thereto) is also replicated in loan crowdfunding.

${ }^{30}$ To be sure, the lines between equity and loan CF can be blurred: in some jurisdictions, such as Germany, hybrid forms, known as profit-participating loans, are most often used. See eg L. Klöhn, L. Hornuf, and T. Schilling, 'Financial Contracting in Crowdinvesting: Lessons from the German Market', working paper, SSRN (2016), 9.
} 
Crowdfunders' motivations may include an element of 'intrinsic' benefit, whereby participation in funding is itself a component of the return. Most obviously, in donation CF, funders derive their returns through the satisfaction of knowing that a cause they value has been furthered. There may also be intrinsic benefits to funding in commercial contexts. For example, a reward CF funder's satisfaction from the product might be enhanced by having had the opportunity to contribute to its development as a member of a community of entrepreneurs and funders. ${ }^{31}$ Even some equity CF investors may enjoy intrinsic benefits-perhaps the satisfaction of being part of a community of investors who interact with the entrepreneur, ${ }^{32}$ or excitement at the opportunity to be an early investor in 'the next Google'. ${ }^{33}$

\section{B The perils of equity crowdfunding}

While equity CF holds out promise for entrepreneurs as a source of financing, it appears highly perilous for investors. Like venture capitalists, equity crowdfunders invest in nascent businesses, with all the associated uncertainty. But unlike a venture capitalist, retail CF investors lack specialist expertise about the prospects of the business projects they back, which leaves them more exposed to poor selection. Nor, continuing the comparison, do they take control rights, because the costs of doing so would outweigh the benefits, given CF investors' lack of expertise and high coordination costs. This lack of control leaves them more exposed than a VC to agency costs- that is, the costs of opportunistic conduct by the entrepreneur after

\footnotetext{
${ }^{31}$ P. Belleflamme, T. Lambert and A. Schwienbacher, 'Crowdfunding: Tapping the Right Crowd' (2014) 29 Journal of Business Venturing 585, 588-589.

32 ibid, 591.

33 A. Schwartz, 'The Nonfinancial Returns of Crowdfunding' (2015) 34 Review of Banking and Financial Law 565, 575-576. A quasi-experiment with Dutch funders, though, found that intrinsic benefits played little part in funders' decisions regarding either type of CF. See M. Cholakova and B. Clarysse, 'Does the Possibility to Make Equity Investments in Crowdfunding Projects Crowd Out Reward-Based Investments?' (2015) 39 Entrepreneurship Theory and Practice 1.
} 
an investment is made. That said, because they do not need to exert resources in exercising control, equity CF investors are in principle able to diversify their investment over a wider portfolio of firms than would a VC. Indeed, equity CF's passive, uninformed and widely diversified investment pattern sounds more like that of traditional retail investors in public equity markets than of VCs investing in start-ups.

Yet if we pursue this alternate comparison, equity CF investors also look more exposed than those investing in public equity markets when it comes to price formation and price informativeness. ${ }^{34}$ In public equity markets, a bevy of mechanisms, including the concurring presence on the market of professional, informed investors, combine to protect retail investors by ensuring that the price swiftly reflects all available information-that is, it is 'informationally efficient'. ${ }^{35}$ In particular, secondary market trading acts to aggregate investors' assessments of the price relevance of publicly available information into the market price extremely rapidly. This makes the market price the best available estimate of the securities’ value, based on publicly available information. Mandatory disclosure obligations for public companies ensure that the set of publicly available information supports informed trading and, hence, accurate pricing. ${ }^{36}$

\footnotetext{
${ }^{34} \mathrm{~A}$ comprehensive comparison between the position of equity CF investors and retail shareholders of publicly traded firms would be out of the scope of this paper. Our focus here is on the lack of an efficient secondary market as an indirect protection tool. At the same time, it is plausible that until an equity-crowdfunded firm becomes a mature successful company, equity CF investors may be less exposed to founders' opportunistic behaviour: startup firms lack free cash flows that can readily be diverted, and founders will be concerned about the need to tap capital markets again in the future.

${ }^{35}$ See generally R. Gilson and R. Kraakman, 'The Mechanisms of Market Efficiency' (1984) 70 Va L Rev 549; B.G. Malkiel, 'The Efficient Market Hypothesis and its Critics’ (2003) 17 J Ec Persp 59; Armour et al, n 18 above, Ch 5.

${ }^{36}$ See R. Kraakman et al, The Anatomy of Corporate Law, $3^{\text {rd }}$ ed (Oxford: OUP, 2017), Ch 9.
} 
On the other hand, there is usually no secondary market for equity CF investments. This means that funders can only invest in equity CF firms in the primary market—whereby firms sell newly issued securities to investors. Of course, that is initially the case for publicly traded shares as well. Yet, an initial public offering ('IPO') on a public equity market is preceded by a 'bookbuilding' process, in which an investment bank will set the initial price based on informed investors' non-binding bids for the securities. In addition, the investment bank's reputation and contacts serve to convince the informed investors to take the process seriously, and to add further credibility it undertakes to underwrite any shortfall.

In contrast, equity CF offerings are far more basic: the issuer typically offers the securities directly to retail investors, without any bookbuilding process or similar mechanism. ${ }^{37}$ CF platforms provide access to information about the company's (self-produced) valuation, its business plan, the target amount, and the percentage of equity it represents based on the valuation. Typically, information is also provided about how much funding the crowd has already committed, and how many investors have already committed to funding. The offer is generally made contingent on enough commitments being made to meet the issuer's selfdeclared funding target. ${ }^{38}$

\footnotetext{
${ }^{37}$ Loan crowdfunding platforms do use auction mechanisms: see J. Franks, N. Serrano-Velarde and O. Sussman, 'Marketplace Lending, Information Efficiency, and Liquidity', working paper (2016).

${ }^{38}$ That is the case for many UK equity CF platforms, such as Crowdcube (see https://help.crowdcube.com/hc/enus/articles/206232524-What-happens-if-I-don-t-reach-my-target-), $\quad$ Seedrs https://www.seedrs.com/learn/guides/creating-a-campaign), and The Right Crowd (see http://therightcrowd.com/faqs/). The SEC crowdfunding regulations mandate a target amount. See Securities and Exchange Commission, n 8 above, 71538.
} 
Theory suggests that, rather than serving to aggregate information, the sequential arrival of investors is likely to engender herding. ${ }^{39}$ In a secondary market, investors assess their own valuation of the security against that reflected in the market price, which adjusts depending on demand. With equity CF, the price neither changes in response to demand nor reflects informed investors' bids. Investors therefore draw inferences about the accuracy of the price from the level of observed demand.

Herding in CF can be illustrated with the following simple model. ${ }^{40}$ Assume that there are $n$ persons who consider an opportunity on a CF platform. Each person $i$ does so in sequence, for $i=i_{1}$ to $i_{\mathrm{n}}$, with earlier investment decisions made known to subsequent arrivals. Some proportion $\Phi$ of the persons (such that $0<\Phi<1$ ) have incomplete pieces of information about the quality of the opportunity. Assume that the investors can determine whether a piece of information is positive or negative with respect to the opportunity's prospects, but because they are not experts, they cannot tell how strong the signal is. Assume further that the probability of any piece of information being positive or negative is equal (that is, 0.5 ), and that investors do not invest unless they are aware of some positive information, and of more positive than negative information.

It follows that when $i_{1}$ considers the investment, she will only invest if she has positive information. If $i_{1}$ invests, then $i_{2}$ can subsequently infer from $i_{1}$ 's investment that $i_{1}$ had positive information, and this increases the probability that $i_{2}$ will invest. Clearly, $i_{2}$ will invest if she has positive information of her own. But even if she has no information of her own, she can still infer the existence of $i_{1}$ 's positive information from the latter's actions, and so will now

\footnotetext{
${ }^{39}$ See AV Banerjee, ‘A Simple Model of Herd Behavior’ (1992) 107 QJE 797.

${ }^{40}$ This is a simplification of Banerjee's model, ibid.
} 
invest. Conversely, if $i_{2}$ has negative information, she will not invest: her negative information will 'cancel out' the positive information she infers from $i_{1}$ 's investment.

Now consider what happens when $i_{3}$ arrives. If both $i_{1}$ and $i_{2}$ invested, then $i_{3}$ will now invest regardless of her own information. This is because $i_{3}$ now makes the inference that at least $i_{1}$, and possibly also $i_{2}$, had positive information. If $i_{3}$ has no information, or has positive information, then the analysis is the same as for $i_{2}$. However, $i_{3}$ will now invest even if she has negative information. In this case she will infer that there are $1+\Phi$ positive pieces of information, as she can infer with certainty that $i_{1}$ had positive information, and the probability that $i_{2}$ had positive information, conditional on having invested, is $\Phi .{ }^{41}$ Consequently the positive information $i_{3}$ infers exceeds the negative information she has. The effect is $a$ fortiori for subsequent investors, who will now all make the same decision: the actions of the first two have triggered an 'information cascade'. This result turns on the fact that subsequent arrivals are unable to distinguish, amongst prior investors, between those who invested on the basis of positive information and those who invested simply on the basis of inferences, with no information of their own. ${ }^{42}$

Herding is borne out in CF practice. It is well-known in the sector that 'momentum' is crucial to the success of CF projects: ${ }^{43}$ if a significant number of funders can be contracted

\footnotetext{
${ }^{41}$ The probability that $i_{2}$ has no information is $(1-\Phi)$, and the probability she has any information is $\Phi$. By investing, $i_{2}$ reveals that she does not have negative information. Thus, if she does have information, it must be positive-so the probability she has positive information is the same as the probability she has any information.

42 As we shall see in our discussion of market mechanisms (below, text to nn 145-151), this effect can be reduced by mechanisms that reveal more information about the characteristics of early investors.

${ }^{43}$ As a leading UK equity crowdfunding platform bluntly puts it in its online guidance for founders: '[i]f you can create early momentum and interest your pitch has a much greater chance of success so lining up investors before you go live is imperative’. See Crowdcube, 'Entrepreneur's Guide to the Crowdcube Crowdfunding Process', https://www.crowdcube.com/pg/the-crowdcube-crowdfunding-process-1371.
} 
quickly, then others will also join. Conversely, a project that does not attract initial support is likely to languish. This suggests a 'bimodal' distribution of funding: that projects should typically either get high levels of support, or very little. This prediction is consistent with casual empiricism. Table 2 presents data from projects offered for investment on Crowdcube.com, a UK-based equity CF portal, in January 2015 and October 2016. For a total of 43 projects offered, the average level of funding received was 42 per cent of the founders' target. However, this masks a bimodal distribution: 26 per cent of offers received more than three-quarters of their target, 63 per cent received one quarter or less of their target, but only 12 per cent received between one-quarter and three-quarters of their target. These results, which complement those reported in other studies, ${ }^{44}$ are consistent with theoretical predictions of herding. ${ }^{45}$

Table 2: Level of funding, relative to target, for Crowdcube projects

\begin{tabular}{|l|r|r|r|r|r|r|}
\hline Date & \multicolumn{2}{|c|}{ Jan 2015} & \multicolumn{2}{c|}{ Oct 2016} & \multicolumn{2}{c|}{ Mean } \\
\hline & \multicolumn{1}{|c|}{ No } & \multicolumn{1}{c|}{$\%$} & \multicolumn{1}{c|}{ No } & \multicolumn{1}{c|}{$\%$} & \multicolumn{1}{c|}{ No } & \multicolumn{1}{c|}{$\%$} \\
\hline All offers & 28 & 100 & 15 & 100 & 43 & 100 \\
\hline & & & & & & \\
\hline Funded to $>=75 \%$ of target & 7 & 25 & 4 & 27 & 11 & 26 \\
\hline Funded to $>25 \%$ but $<75 \%$ of target & 2 & 7 & 3 & 20 & 5 & 12 \\
\hline Funded to $<=25 \%$ of target & 19 & 68 & 8 & 53 & 27 & 63 \\
\hline & & & & & & \\
\hline Mean proportion funded & & 37 & & 49 & & 42 \\
\hline
\end{tabular}

Notes: data are taken from investment opportunities available on Crowdcube.com on 23 January 2015 and 5 October 2016 respectively. Because of rounding, percentages do not sum exactly to 100 in all cases.

Where herding occurs, funders as a group behave as if they attach great significance to the information possessed by early arrivals and little or no significance to that possessed by

\footnotetext{
${ }^{44}$ See eg S. Vismara, 'Information Cascades Among Investors in Equity Crowdfunding' (forthcoming) Entrepreneurship Theory and Practice.

${ }^{45}$ A complementary explanation for the U-shaped support pattern is that, as mentioned above (text preceding $n$ 38) equity CF campaigns have a funding target. Subsequent funders may be more inclined to back campaigns that are closer to the target in order to reduce the expected opportunity costs of committing time and possibly funds (depending on the platform terms) to those which may then fail.
} 
later arrivals, even if — as we assumed in the foregoing analysis — the information is all of equal quality. This means that the quality of decision-making will be lower than a process that makes use of all the information available to the group. Herding consequently results in a misallocation of resources_-overinvestment in projects for which the prospects are weak and underinvestment in projects for which the prospects are strong-which will consequently reduce returns to investors.

In reality, there is likely to be a bias towards overinvestment, for two reasons. First, all that is reported is some information about prior positive funding decisions, but there is nothing about investors who considered the opportunity and declined to invest. Here, all that subsequent investors can do is to draw inferences based on the amount of time for which an offer has remained open. If it has been open for a while and has received no investment, then people considering it will assume that the number of persons who have passed it over is 'large' and so any investment at this stage will be unlikely. Second, and more perniciously, empirical studies report that initial investors are disproportionately likely to be friends and family of the founders, whose assessment of the project's merits are likely to be strongly biased in favour. ${ }^{46}$ If herding follows, this will consequently bias the collective decision. Given the foregoing perils, equity CF is probably the riskiest (non-leveraged) investment class a retail investor can access.

\section{B The promise of reward crowdfunding}

Reward CF involves raising finance from a firm's (prospective) consumers, who are promised early shipment of units of the product in return for their funding. Like equity CF, the firm

\footnotetext{
${ }^{46}$ Agrawal et al, n 22 above; E. Mollick, 'The Dynamics of Crowdfunding: An Exploratory Study' (2014) 29 Journal of Business Venturing 1; M.G. Colombo, C. Franzoni and C. Rossi-Lamastra, 'Internal Social Capital and the Attraction of Early Contributions in Crowdfunding’ (2015) 39 Entrepreneurship Theory and Practice 75.
} 
contracts with the funders directly, and there is no subsequent trading of claims between funders in a secondary market. However, the fact that the funding technique melds together the capital and product markets means that the interaction amongst funders is quite different.

Reward CF is similar to pre-purchase of a product, save that the entrepreneur typically makes fewer representations regarding the quality of the product, or even its prospects of delivery, than would an established manufacturer. A prominent example of such risk-sharing is found in the Terms of Use offered by Kickstarter, a leading reward CF platform. They provide that the delivery date is an, 'estimate ... not a guarantee to fulfil by that date. The schedule may change as the creator works on the project' ${ }^{47}$ As regards non-delivery, the same terms provide that a creator who is unable to fulfil rewards may alternatively 'me[e]t their obligations to backers' if they: ${ }^{48}$

'post an update that explains what work has been done, how funds were used, and what prevents them from finishing the project as planned; work diligently and in good faith to bring the project to the best possible conclusion in a timeframe that's communicated to backers; ... demonstrate that they've used funds appropriately and made every reasonable effort to complete the project as promised; ... [have] been honest, and ... made no material misrepresentations in their communication to backers; and ... offer to return any remaining funds to backers who have not received their reward (in

\footnotetext{
${ }^{47}$ Kickstarter, Terms of Use, clause 5 (https://www.kickstarter.com/terms-of-use). The Terms of Use clearly appear to be intended to govern not only relations between users and the Kickstarter platform, but also between users and each other.

${ }^{48}$ ibid, clause 4. Entrepreneurs, not the portal itself, are solely responsible for the fulfilment of their reward obligations: ibid, clause 6 .
} 
proportion to the amounts pledged), or else explain how those funds will be used to complete the project in some alternate form'.

This clearly establishes a different risk allocation from that normally found in a contract for the sale of goods, and one that is specific to the circumstances of experimental development of a product on behalf of a group of enthusiasts. This risk-sharing is accepted by the funders because of the innovative nature of the product. ${ }^{49}$ Funders are people who have a strong preference for the product offered and, because it is innovative, are unable to satisfy that preference elsewhere. For the funders, their preference for the product is so strong that it is worth paying even for a less-than-certain prospect of getting it.

Of course, such risk-sharing leaves funders exposed to agency costs, but these are mitigated by the introduction of a requirement of good faith in performance by the founder, along with an obligation to demonstrate why any outcome has resulted other than delivery. ${ }^{50}$ Such terms echo contractual mechanisms commonly used in agreements between sophisticated parties relating to the joint production of technological innovation. ${ }^{51}$ An early study of reward CF suggests that non-delivery is in fact rare for projects using reward CF: less than five per

\footnotetext{
${ }^{49}$ As explained in Kickstarter's FAQ: 'backers must understand that Kickstarter is not a store. When you back a project, you're helping to create something new — not ordering something that already exists. There's a chance something could happen that prevents the creator from being able to finish the project as promised'. (FAQ: 'What is a creator obligated to do once their project is funded?', available at https://www.kickstarter.com/help/faq/kickstarter+basics?ref=footer).

${ }^{50}$ Text to n 48. Similarly, the terms of use of another leading reward CF platform, Indiegogo, appear to create mutual obligations of good faith regarding resolution of non-delivery: 'If a Campaign Owner is unable to perform on any promise and/or commitment to Contributors, the Campaign Owner will work with the Contributors to reach a mutually satisfactory resolution, which may include refunding Contributions' (Indiegogo Inc, Terms of Use, available at https://www.indiegogo.com/about/terms).

${ }^{51}$ See eg R.J. Gilson, C.F. Sabel and R.E. Scott, 'Braiding: The Interaction of Formal and Informal Contracting in Theory, Practice and Doctrine’ (2010) 110 Colum L Rev 1377, 1424-1431.
} 
cent of founders failed to deliver, although over 75 per cent delivered the product later than indicated in their pitch. ${ }^{52}$

The key distinction between reward and equity CF is the nature of the funder's material payoff. ${ }^{53}$ With equity CF, the value of the payoff equals the return on the investment, which depends, inter alia, on whether shares were priced fairly, ${ }^{54}$ how successful the business is in general, and how loyal the founders are towards the CF investors, that is, on a number of factors that a typical retail investor is unlikely to be able to assess. In contrast, the payoff in reward CF is a unit of the product. The value of this depends on the strength of the funder's preference for the product. This is something known only to the funder, and in respect of which the funder is expert. Where preferences differ among people, the possibility of herding is greatly reduced. ${ }^{55}$ This is because the inference that can be drawn from earlier funders' support depends on these funders' preferences regarding the product, which will not generalise in the same way as expectations of financial returns.

Moreover, a decision to fund reveals previously private information about the funder's preference for the product. By making the funding call conditional on a sufficient amount of finance being raised, the entrepreneur can use a reward CF round as a way of determining

\footnotetext{
${ }^{52}$ Mollick, n 46 above, 11-12.

${ }^{53}$ On funders' intrinsic motivations to engage in CF see text to $\mathrm{nn}$ 31-33.

${ }^{54}$ Problems with pricing are compounded if, as seems plausible, retail investors are liable to conflate their expectations about the success of the firm's product with the likely success of the investment. ${ }^{55}$ See eg S. Bikhchandani, D. Hirshleifer, and I. Welch, 'Learning from the Behavior of Others: Conformity, Fads, and Informational Cascades’ (1998) 12 J Ec Persp 151, 161.

${ }^{55}$ See eg S. Bikhchandani, D. Hirshleifer, and I. Welch, 'Learning from the Behavior of Others: Conformity, Fads, and Informational Cascades’ (1998) 12 J Ec Persp 151, 161.
} 
whether or not there is sufficient demand for the product. ${ }^{56}$ Thus the entrepreneur gets a 'forward' picture of the putative product market and raises funding at the same time.

Of course, a decision to fund reflects not only the funder's preference for the product, but also their assessment of the likelihood that it will be delivered. In fact, the decision to fund itself increases the chances of the product reaching the market, which has informational value for later backers.

To conclude, the synergy between product and capital markets that reward CF entails makes it a much more informative funding technique than equity CF. It also makes it much more difficult to conclude that funders are getting a poor return: the natural inference from funding is that funders want the product so much they are prepared to take the risk of nondelivery.

\section{A Regulating crowdfunding in the UK and US}

Having described the features of the two types of CF contract for start-up firms, we now consider how they are regulated. In so doing, we focus on the UK and the US. The UK's regulation of equity $\mathrm{CF}$ is of relevance not just for the domestic market, but potentially also as a model for other jurisdictions. Much of the content of UK securities law is derived from EU legislation, ${ }^{57}$ and more than half of all the equity CF platforms operating in the EU are based in the UK. ${ }^{58}$ In turn, the US, home to the world's largest venture capital investment community

\footnotetext{
${ }^{56}$ See A. Agrawal, C. Catalini and A. Goldfarb, 'Some Simple Economics of Crowdfunding' (2014) 14 Innovation Policy and the Economy 63, 68.

${ }^{57}$ While the UK's membership of the EU is now foreshortened, most of the relevant EU law rules have been enacted as part of UK domestic law, or look likely to be so enacted as part of the process of exiting. We therefore expect them to remain relevant for at least the foreseeable future.

${ }^{58}$ ESMA, Investment-Based Crowdfunding: Insights from Regulators in the EU, ESMA/2015/856 Ann 1 (2015), 2.
} 
and capital markets, has long been acknowledged to be a leader in the provision of finance for innovation.

These two countries have taken very different approaches to the regulation of CF. The UK, making use of an exemption to EU securities laws permitting a 'small offering exemption', imposes no detailed disclosure obligations on equity CF. On the other hand, the US applies burdensome disclosure regulations to equity $\mathrm{CF}$ —albeit watered down for small firms —as it does to all issues of securities to the public. Yet when we turn to reward CF, a battery of consumer protection laws-mainly derived from the EU acquis-are applicable in the UK, whereas there is no equivalent in the US.

\section{B Equity CF}

The UK has implemented in full an optional exemption under the EU’s Prospectus Directive for securities offerings amounting to less than $€ 5$ million by a single firm in a 12-month period. ${ }^{59}$ This facilitates CF offerings by exempting relevant issuers from the obligation to prepare a prospectus - a very significant saving in compliance costs. ${ }^{60}$

Nevertheless, portals offering equity CF in the UK must be authorised by the FCA, because they carry out financial promotions and arrange deals in investments. ${ }^{61}$ This requirement is grounded in EU law: under the Markets in Financial Instruments Directive ('MiFID'), all firms engaged in the business of receiving and transmitting orders relating to

\footnotetext{
${ }^{59}$ Financial Services and Markets Act 2000 ('FSMA'), s 85(5)(a), Sch 11A, para 9; Prospectus Directive 2003/71/EC [2003] OJ L 345/64 (as amended) (the 'Prospectus Directive'), Art 1(2)(h). The exemption is permissive, thus granting member states discretion to regulate smaller offerings.

${ }^{60}$ See, text to n 19 above.

${ }^{61}$ FSMA ss 19, 21; Financial Services and Markets Act 2000 (Regulated Activities) Order 2001, SI 2001/554, Art 25.
} 
financial instruments must be authorised by the national competent authority, ${ }^{62}$ and equity CF offerings, provided they are in principle transferable, fall within the definition of 'financial instruments’ ${ }^{63}$

The FCA introduced specific investor protection rules for equity CF platforms in 2014, regularising what had until then been an ad hoc approach to authorisation. ${ }^{64}$ Pursuant to the MiFID regime, these rules subject authorised CF platforms to conduct of business obligations. There is a general obligation to ensure that financial promotions offered on the platform, which of course include founders' pitches, are 'fair, clear and not misleading', ${ }^{65}$ and a requirement that the platform (or the investor's financial adviser) assess whether CF securities are appropriate for an investor client, by determining whether the investor has the 'necessary knowledge and experience to understand the risks involved'. ${ }^{66}$ In practice, this is met by requiring investors to answer a simple automated test about the characteristics of equity $\mathrm{CF}$ investments, for which guidance is provided.

\footnotetext{
${ }^{62}$ Markets in Financial Instruments Directive ('MiFID') 2004/39/EC [2004] OJ L145/1, Art 5(1) (requirement for authorisation), Art 4(1)(2) and Annex I, Section A ('investment services and activities'). From 1 January 2018, Markets in Financial Instruments Directive (recast) ('MiFID II') 2014/65/EU [2014] OJ L 173/349, Arts 5(1), 4(1)(2) and Annex I, Section A. See also ESMA, 'Opinion: Investment-based Crowdfunding', ESMA/2014/1378, 18 December 2014, 13-15.

${ }^{63}$ MiFID, Annex I, Section C ('financial instruments' includes 'transferable securities', in turn defined in Art 4(1)(18)); see similarly MiFID II, Annex I Section C and Art 4(1)(44). While in some member states, CF platforms have avoided this obligation by marketing only non-transferable securities (see ESMA, n 62 above, 14), the UK implementation as ‘financial promotions' (n 61 above) also encompasses these.

${ }^{64}$ See FCA, The FCA's Regulatory Approach, $\mathrm{n} 7$ above.

${ }^{65}$ FCA, Conduct of Business Sourcebook ('COBS') 4.2.1R. This implements MiFID, Art 19(2) (MiFID II, Art 24(3)).

${ }^{66}$ COBS 4.7.7(3), 4.7.8(2), 10.2. The 'appropriateness' obligation implements MiFID, Art 19(5) (MiFID II, Art 25(3)).
} 
In addition, the FCA introduced restrictions on the extent to which individuals may invest in equity CF. Equity CF securities may only be offered to sophisticated investors or to retail investors who certify that they have not invested, and will not invest, more than 10 per cent of their net assets in non-readily realisable securities. ${ }^{67}$

The starting point for equity CF in the US was, in contrast to the UK, a securities law regime that until recently had no exemption for small offers. Title II of the JOBS Act of 2012 removed obstacles to the setup of equity CF platforms, but limited access to accredited investors (high net worth individuals). ${ }^{68}$ Then, under Title III of the JOBS Act, ${ }^{69}$ Congress inaugurated a 'small offering' regime for firms raising no more than $\$ 1$ million over a 12month period, ${ }^{70}$ and directed the SEC to pass associated rules. The SEC did not adopt its final 'Regulation Crowdfunding' ('Regulation CF') until October 2015, which came into force in May 2016. ${ }^{71}$

In some respects, the conditions for issuing under Regulation CF echo the regulatory treatment of equity CF in the UK. In particular, equity CF transactions must be conducted through an intermediary registered with the SEC, as either a broker or a new type of regulated entity called a 'funding portal', which must take steps to ensure investors understand the risks

\footnotetext{
${ }^{67}$ COBS 4.7.7(2), 4.7.9-4.7.10.

${ }^{68}$ Individuals are 'accredited investors' if they have net worth (excluding their home) exceeding \$1m, or annual income exceeding \$200,000 (or \$300,000 jointly with their spouse): SEC Regulation D, Rule 501 (17 CFR § 230.501). Such persons are presumed to be able to afford access to financial advice.

${ }^{69}$ Jumpstart Our Business Startups Act, Pub L. No. 112-106, 126 Stat. 306 (2012) (the 'JOBS Act'). Title III of the JOBS Act may also be cited as the 'Capital Raising Online While Deterring Fraud and Unethical NonDisclosure Act of 2012' or the 'CROWDFUND Act'.

${ }^{70}$ Securities Act of $1933 \S 4(a)(6)$.

${ }^{71}$ See $n 8$ above.
} 
involved. ${ }^{72}$ Intermediaries must have a reasonable basis for believing that issuers on their platform are in compliance with relevant regulations, and must deny access to issuers they believe may present potential for fraud. ${ }^{73}$ To avoid conflicts of interest, an intermediary’s directors, officers and partners are prohibited from taking any financial interest in issuers using its services. ${ }^{74}$

There are also quantitative restrictions on the exposure of retail investors, althoughin contrast to the UK rules - these restrict the amount that may be invested per issuer, ${ }^{75}$ as opposed to in the asset class as a whole. In order to prevent evasion of the foregoing restrictions, securities issued in a CF transaction may not be transferred by a purchaser within a year, although they are freely transferable thereafter. ${ }^{76}$

Where US regulatory environment for equity CF differs most significantly from the UK is as regards mandatory disclosure. US equity CF issuers must file an extensive list of disclosures with the SEC, and also make them available to potential investors via the CF platform. ${ }^{77}$ They must also provide a complete set of financial statements, prepared under US

\footnotetext{
${ }^{72}$ Securities Act of $1933 \S \S 4(\mathrm{a})(6)(C), 4 \mathrm{~A}(\mathrm{a})$. As of the time of writing, 27 funding portals had registered with the SEC. See https://www.finra.org/about/funding-portals-we-regulate.

${ }^{73}$ Securities Act of $1933 \S 4 \mathrm{~A}(\mathrm{a})(5)$. The intermediary is entitled to rely on representations from the issuer, absent knowledge or indications to the contrary.

${ }^{74}$ ibid § 4A(a)(11).

${ }^{75}$ ibid § 4(a)(6)(B). For an investor whose annual income and net worth are both below $\$ 100,000$, the maximum that may be invested in a single issuer is $\$ 2,000$ or 5 per cent of annual income or net worth, whichever is greater. If either the investor's annual income or net worth exceeds $\$ 100,000$, a limit of 10 per cent of annual income or net worth, whichever is greater, but not to exceed $\$ 100,000$, applies.

${ }^{76}$ ibid $\S 4(a)(3)$. See also SEC, n 8 above, 71475. There are exceptions for resales to the issuer or to accredited investors.

${ }^{77}$ Securities Act of $1933 \S 4 \mathrm{~A}(\mathrm{~b})(1)(\mathrm{A})-(\mathrm{H})$. These include information on directors, officers and principal shareholders; the issuer's business and business plan; the purpose and use of proceeds of the offering; the price of
} 
GAAP, for the previous two years or the period since formation, whichever is shorter, and provide a narrative discussion of its historical results, liquidity and capital resources. ${ }^{78}$ The degree of required external scrutiny of the financial statements increases with the size of the offering: the smallest issues (up to $\$ 100,000$ ) need only be certified by the issuer's CEO, whereas larger issues (above $\$ 500,000$ ) must be fully audited. ${ }^{79}$ Having completed an equity CF issue, there is then an ongoing obligation to file annual reports with the SEC. ${ }^{80}$

Crowdfunding investors may bring actions against issuers for material misstatements or omissions in the offering documents. ${ }^{81}$ Depending on the circumstances, CF intermediaries may also be treated as 'issuers' for the purposes of liability. ${ }^{82}$ Intermediaries consequently conduct due diligence on potential issuers before deciding whether to allow them to list their securities for sale on their platform.

The SEC's own estimates of compliance costs suggest that Regulation CF may not be appealing for issuers seeking to raise smaller amounts. The agency estimated that the fixed costs for required filings would be $\$ 6,460$ and that intermediaries would charge between five and 15 per cent of the amount raised: for a $\$ 100,000$ offering, such costs and fees may be as

the securities or the method of its determination; the target offering amount and the deadline to reach it; the ownership and capital structure of the issuer; and any risk factors related to the offering. SEC rules additionally mandate disclosure of fees paid by the issuer to the intermediary; material risk factors affecting the issuer's business; the material terms of its debt; and certain related-party transactions (ibid § $4 \mathrm{~A}(\mathrm{~b})(1)(\mathrm{I}), 17 \mathrm{CFR} \S$ 227.201).

\footnotetext{
${ }^{78}$ Securities Act of $1933 \S 4 A(b)(1)(D)$.

${ }^{79} \mathrm{ibid}$. Issues of between $\$ 100,000$ to $\$ 500,000$ must be reviewed by an independent public accountant.

80 ibid § 4A(b)(4).

81 ibid § $4 \mathrm{~A}(\mathrm{c})$.

${ }^{82}$ The SEC has pointedly declined to exclude CF intermediaries from the definition of 'issuers': see SEC, n 8 above, 71477-71479.
} 
high as 21.5 per cent of the capital raised. ${ }^{83}$ This contrasts unfavourably with the costs of an equity CF offer in the UK or a reward CF offer in the US, where platform and payment service provider fees are in the region of eight to ten per cent of the funds raised. ${ }^{84}$ These additional costs will make US equity CF offerings less attractive to founders. ${ }^{85}$ A total of $\$ 12.5$ million is estimated to have been raised under Regulation CF in the first six months of its operation. ${ }^{86}$ This looks very modest when it is borne in mind that approximately $\$ 600$ million was raised in US reward CF in the corresponding period of the previous year. ${ }^{87}$

To summarise, the US imposes a much more onerous regulatory regime for equity CF than does the UK. Raising equity CF from retail investors was not permitted at all in the US until May 2016. Going forwards, the contrast between the regulation of equity CF in the UK and US turns on the application of mandatory disclosure. The more onerous US rules have inhibited the development of the equity CF market, and appear to make equity CF issues more

\footnotetext{
${ }^{83}$ See SEC, 'Proposed Rules: Crowdfunding’ (2013) 78 Federal Register 66436, 66521.

${ }^{84}$ See eg Crowdcube, 'Crowdcube Fees', available at https://www.crowdcube.com/pg/crowdcubefees-34; Kickstarter, 'FAQ: What are the fees?', available at https://www.kickstarter.com/help/faq/kickstarter+basics?ref=footer.

${ }^{85}$ For example, in the case described in the text, the equity actually contributed to the issuer's operations would only be $\$ 78,540$ and it would need to increase in value by $\$ 21,460$ (27.3 per cent) before it would even reach investors' break-even valuation of $\$ 100,000$. Because fees are a fixed cost, they consume a smaller fraction of larger offerings: for a $\$ 1$ million offering, anticipated costs would be between 8.5-18.5 per cent of the offering.
}

86 A. Wan, 'A Comparison of Reg CF and Reg A-Plus', Law360.com, 14 March 2017 (https://www.law360.com/articles/901763/a-comparison-of-reg-cf-and-reg-a-plus).

${ }^{87}$ Globally \$2,055m was raised by way of reward CF during 2015, or \$514m per quarter (Table 1 above). The US accounts for around 60 per cent of global CF activity (Massolution, n 24 above, 58). 
costly in that country going forwards. ${ }^{88}$ However-as we shall see-when we turn to reward $\mathrm{CF}$, this jurisdictional pattern of regulatory intensity and market success is reversed.

\section{B Reward CF}

Reward CF contracts are (conditional) undertakings to transfer title to future goods, or to provide future services. ${ }^{89}$ Although the funder bears part of the risk of business failure, these contracts are neither designed to be cash-settled nor involve the funder receiving a return that varies with the profitability of the business. Consequently they are not classified as 'financial instruments' or 'securities'. ${ }^{90}$ As a result, reward CF is not regulated as a public offer by the FCA in the UK or as a securities offering by the SEC in the US. ${ }^{91}$ Rather, offerings of this type are subject to general contract law and consumer protection obligations, because entrepreneurs raising funds are doing so in the course of their business, whereas reward backers are typically acting as individuals outside the course of their business.

Contract law is a matter for state law in the US, although all states have adopted the Uniform Commercial Code, which governs sales contracts. This provides standard remedies

\footnotetext{
${ }^{88}$ The extent to which such higher regulatory costs impact the level of equity CF raised is of course also a function of other factors affecting demand for funding, including stronger markets for venture capital and angel investment.

${ }^{89}$ See eg UK platform Crowdfunder, http://www.crowdfunder.co.uk/rewards-page (distinguishing reward from donative CF: 'pre-sell your product ... [e]veryone wants something for their money').

${ }^{90}$ For the EU, see MiFID, Art 4(1)(17) and Annex I, Part C (defining 'financial instruments') (see similarly MiFID II, Art 4(1)(15) and Annex I, Part C); for the US, see Securities Act of 1933 § 2(a)(1) (defining 'security') and United Housing Foundation, Inc v Forman 421 US 837 (1975), 852-53 ('[W]hen a purchaser is motivated by a desire to use or consume the item purchased ... the securities laws do not apply').

${ }^{91}$ FCA, Call for Input, n 7 above, 6 n 2.
} 
for late delivery and delivery of goods not matching their description or fitness for purpose. ${ }^{92}$ However, parties may waive such protections by express contractual provision. ${ }^{93}$

States typically also have consumer protection laws, albeit rather narrower in their scope and less coherent in their organisation than the regime established in the EU. For example, New York, which is the governing law for Kickstarter's Terms of Use, ${ }^{94}$ has general provisions requiring agreements governing consumer transactions to be written in 'plain language’ and not in very small print, ${ }^{95}$ which appear to be readily met by Kickstarter's terms.

Many states also have general provisions prohibiting 'deceptive acts or practices' in consumer transactions. ${ }^{96}$ These provisions may be invoked to protect citizens of the state in question who entered into reward CF transactions under the laws of other states. For example, in State of Washington $v$ Altius Management $L L C,{ }^{97}$ the Attorney General of Washington State successfully obtained a default judgment under Washington’s equivalent general prohibition ${ }^{98}$ against a firm and its owner that had failed to deliver rewards (or even communicate) over a period of several years since running a successful funding campaign on Kickstarter. Kickstarter's Terms of Use at the time stipulated that founders of commercial projects were

\footnotetext{
${ }^{92}$ UCC §§ 2-313, 2-314, 2-601.

${ }^{93}$ ibid, §§ 2-303, 2-316, 2-317.

${ }^{94}$ Kickstarter, Terms of Use, n 47 above, clause 17.

${ }^{95}$ NY General Obligations Law § 5-702; NY Civil Practice Law and Rules § 4544.

${ }^{96}$ NY General Business Law § 349.

${ }^{97}$ King County Superior Court, Washington State, 22 July 2015.

${ }^{98}$ Revised Code of Washington $\S 19.86 .020$ (prohibiting 'unfair or deceptive acts or practices in the conduct of any trade or commerce'). The Attorney General represented Washington State citizens who had backed the defendant's Kickstarter campaign.
} 
required to offer a refund if they were unable to fulfil rewards, ${ }^{99}$ and the judge reasoned that failure to do so violated the statute. However, Kickstarter subsequently modified its terms, as discussed above, ${ }^{100}$ to make clear that non-delivery would not be a breach provided the founder can account for how the money has been spent in pursuit of the project. The resulting position appears to be that misrepresentation or, a fortiori, fraud, may violate such statutes, but that delivery failures, whether explained by reference to technological impossibility or even in the presence of a pattern of timely and open communications with funders and best-effort, but fruitless attempts to deliver on the promises, will not.

Matters are very different in the UK (and indeed the EU more generally), where several mandatory rules of consumer contract law appear to be applicable to reward CF agreements. First, founders offering their products as rewards are likely to find that funders will enjoy nonwaivable rights to a refund after delivery of goods or commencement of a service if they are unhappy with the quality of what they receive. The most extensive such entitlement is the unconditional 'right to cancel' under the Consumer Contracts (Information, Cancellation and Additional Charges) Regulations 2013 (the 'CCRs'), ${ }^{101}$ which implement the EU’s Consumer Rights Directive. ${ }^{102}$ The CCRs grant consumers purchasing under a distance sales contract an unconditional right to cancel within 14 days of receipt of the goods, whereupon the supplier

\footnotetext{
${ }^{99}$ Kickstarter, Terms of Use October 2012 (applicable to projects launched before 18 October 2014), available at https://www.kickstarter.com/terms-of-use/oct2012?country=US ('Project Creators are required to fulfil all rewards of successful fundraising campaigns or refund any Backer whose reward they do not or cannot fulfil').

${ }^{100}$ See, text to nn 47-49 above.

${ }^{101}$ SI 2013/3134. The CCRs replaced the earlier Consumer Protection (Distance Selling) Regulations 2000, SI 2000/2334.

102 2011/83/EC [2011] OJ L304/64. This replaced Directive 97/7/EC on the protection of consumers in respect of distance contracts and directive 85/577/EC to protect consumers in respect of contracts negotiated away from business premises.
} 
must reimburse the amount paid by the consumer. ${ }^{103} \mathrm{~A}$ 'sales contract' is defined as 'a contract under which a trader ... agrees to transfer the ownership of goods to a consumer and the consumer pays or agrees to pay the price', including any contract that has both goods and services as its object', ${ }^{104}$ which would seem apt to cover many cases of reward CF. Although financial services contracts, defined as 'services of a banking, credit, insurance, personal pension, investment or payment nature,' are excluded from the CCRs, ${ }^{105}$ a typical reward CF arrangement would not fall within the scope of this exclusion. ${ }^{106}$ There may also be similar, albeit more circumscribed, mandatory cancellation rights available for longer periods under the Consumer Rights Act 2015, ${ }^{107}$ or the Unfair Trading Regulations 2008 (the 'UTRs'). ${ }^{108}$

\footnotetext{
${ }^{103}$ CCRs, n 101 above, rr 4-6 and Part 3. This right to cancel is subject to an exclusion for 'goods that are made to the consumer's specifications or are clearly personalised' (ibid, reg 28(1)(b)), which might exempt some, but by no means all, instances of reward CF. There is also an exclusion for goods and services for which 'the price is dependent on fluctuations in the financial market which cannot be controlled by the trader' (ibid, reg 28(1)(a)), which does not on its face extend to reward CF.
}

${ }^{104}$ CCRs, n 101 above, r 5.

105 ibid, r 6.

${ }^{106}$ While parties might in theory seek to engage the exemption by structuring reward CF arrangements as loans from the funder to the founder, which the latter then repays in kind, it is doubtful whether a court would accept such a label as denying the transaction the status of a 'sales contract', and the consumer the associated protection (see generally Snook v London and West Riding Investments Ltd [1967] 2 QQB 786, 802; Street $v$ Mountford [1985] AC 809, 826-827; Welsh Development Agency v Export Finance Co Ltd [1992] BCLC 148, 160-163; Bankway Properties Ltd v Pensfold-Dunsford [2001] EWCA Civ 528, [2001] 1 WLR 1369 at [42]-[44]; Autoclenz Ltd v Belcher [2011] UKSC 41, [2011] IRLR 820 at [23]-[29]).

${ }^{107}$ Sections 3, 9 and 20 (consumer contracts 'for a trader to supply goods', including not only 'sales' but also contracts for 'transfer of goods', confer on consumers the right to reject goods and receive refund within 30 days of receipt if goods not of satisfactory quality given their marketing).

108 SI 2008/1277 (implementing the EU’s Unfair Commercial Practices Directive 2005/29/EC [2005] OJ L149/22), Part 4A rr 27A, 27E, 27J-27K (contracts for sale or supply of goods or services by trader to consumer, giving consumer right to unwind contract and receive refund within 90 days of receipt of goods or commencement 
Second, the UTRs make it a criminal offence of strict liability, punishable by up to two years' imprisonment, for sellers to make misleading statements or to omit material information in relation to consumer contracts. ${ }^{109}$ The consequence of this is likely to be an increase in the cost of producing materials describing reward CF offers so as to avoid potential criminal liability.

Third, the Consumer Rights Act, which implements the Unfair Contract Terms Directive, ${ }^{110}$ provides for substantive control of 'fairness' of non-core terms in contracts between businesses and consumers. While specification of the main subject matter and the price are excluded from such scrutiny, ${ }^{111}$ terms purporting to exclude liability for non-delivery or late delivery are not. Attempts by an entrepreneur to make a funder bear the risk of outright non-delivery might well be seen as creating an unfair 'imbalance' in the contract-the consumer having paid the 'price' but the entrepreneur purporting to be relieved of the obligation to deliver. ${ }^{112}$ However, late delivery, given the context, is more likely to be something it would be reasonable to provide for as a contingency. ${ }^{113}$

of service, if funder relied on seller's misleading statement about product, plus damages for reasonably foreseeable consequential loss).

${ }^{109}$ UTRs, regs 5-6, 9-10, 13.

${ }^{110}$ Council Directive 93/13/EEC [1993] OJ L95/29.

${ }^{111}$ Consumer Rights Act 2015 s 64(1).

${ }^{112}$ See ibid Sch 2, para 7 (terms permitting trader to retain sums paid by consumer where trader dissolves the contract are presumptively unfair).

${ }^{113}$ See ibid Sch 2, para 13 (terms permitting trader to alter characteristics of goods without a valid reason presumptively invalid) (emphasis added). ${ }^{114}$ The UK agency that has jurisdiction to enforce violations of consumer contract law, the Competition \& Markets Authority, makes no mention of having undertaken any enforcement or investigation activity in relation to reward CF: see CMA, Consumer Outcomes Secured by the CMA since April 2014, available at https://www.gov.uk/government/publications/consumer-enforcementoutcomes/consumer-outcomes-secured-by-the-cma-since-april-2014. A similar jurisdictional divide is also 
The foregoing points have not received express attention from regulators in the UK, also because reward crowdfunding falls outside the FCA's jurisdiction. ${ }^{114}$ The net effect of these provisions, and especially the right to cancel under the CCRs, appears to upset the risksharing in reward CF described above: ${ }^{115}$ the entrepreneur now bears all the risk that the product does not turn out satisfactorily. This is likely to make reward CF considerably less appealing in the UK than the US for an entrepreneur considering funding options. While there may be other explanations, this variation in treatment is consistent with data on the use of reward CF, which, according to the estimates reported in Table 1, appears to be under-used in the UK relative to the global norm.

Yet, US-based platforms such as Kickstarter accept funding (and projects) from most countries in the world, so UK funders or founders wishing to pursue reward CF might do so by using a US platform instead. While the relevant terms of use will contain jurisdiction and choice of law clauses in favour of a US state-New York, in the case of Kickstarter ${ }^{116}$ — this seems unlikely to escape the consumer safeguards built into the EU's private international law

apparent at the EU level, with DG FSMA having responsibility for, and considering regulating, equity CF but consumer contracts being a matter for DG Justice and Consumers, which has not issued any guidance about reward CF. In some other EU Member States, however, the position may be different.

${ }^{114}$ The UK agency that has jurisdiction to enforce violations of consumer contract law, the Competition \& Markets Authority, makes no mention of having undertaken any enforcement or investigation activity in relation to reward CF: see CMA, Consumer Outcomes Secured by the CMA since April 2014, available at https://www.gov.uk/government/publications/consumer-enforcement-outcomes/consumer-outcomes-securedby-the-cma-since-april-2014. A similar jurisdictional divide is also apparent at the EU level, with DG FSMA having responsibility for, and considering regulating, equity CF but consumer contracts being a matter for DG Justice and Consumers, which has not issued any guidance about reward CF. In some other EU Member States, however, the position may be different.

${ }^{115}$ See, text to nn 47-49 above.

${ }^{116}$ See Kickstarter, Terms of Use, n 47 above, clause 17. 
framework. Where a trader 'directs [commercial] activities' to a consumer's country of residence, mandatory consumer protection rules of that jurisdiction's law will apply regardless of choice of law, ${ }^{117}$ and the consumer is guaranteed the option to sue in the jurisdiction of her domicile, regardless of choice of forum. ${ }^{118}$ According to the case law of the Court of Justice of the European Union, firms can 'direct commercial activities' to consumers in a particular country through a website, provided that the setup of the website contemplates transactions with consumers in that country (for example, by referencing it expressly). ${ }^{119}$ Where the parties are both domiciled in the EU, this would put a brake on UK founders evading the domestic consumer protection regime by seeking to raise reward CF on a US platform. ${ }^{120}$

To conclude this section, we briefly review the main points of contrast. The UK’s consumer protection framework makes it difficult to establish a risk-sharing agreement for reward CF, whereas the rules applicable in the US do not. In contrast, the mandatory disclosure obligations imposed by US securities law make it very expensive to launch equity CF campaigns there, whereas the exemption for small offers in the UK does not. The differences in regulation appear to matter on the ground, being aligned with relatively greater use of reward CF in the US, and equity CF in the UK. Yet can the very different treatment-within both the

\footnotetext{
${ }^{117}$ Regulation (EC) No 593/2008 on the Law Applicable to Contractual Relations (Rome I) [2008] OJ L177/6, Art 6.

${ }^{118}$ Regulation (EU) No 1215/2012 on Jurisdiction and the Recognition and Enforcement of Judgments in Civil and Commercial Matters (recast) [2012] OJ L351/1, Arts 6(1), 17, 18.

${ }^{119}$ See Cases C-585/08 and C-144/09, Pammer and Hotel Alpenhof GesmbH ECLI:EU:C:2010:740; See also Case C-190/11, Mühlleitner ECLI:EU:C:2012:542.

${ }^{120}$ However, difficulties with recognition and enforcement of judgments likely undermine the efficacy of such protection as regards founders based outside the EU. Consistently with this, we understand it is reasonably common for US founders to raise funds on Kickstarter from EU backers.
} 
UK and the US — of these functionally quite similar activities be justified? In the next section, we address CF regulation from a normative perspective.

\section{A How should crowdfunding be regulated?}

From a legal perspective, CF sits in territory at the intersection of securities markets and consumer protection law. While these two fields pursue similar general regulatory goalsprotecting the interests of less informed parties - they do so by very different routes. As a novel practice, CF has found itself regulated by these existing bodies of rules. This treats CF as if it were analogous to longer-established-and better-understood-activities. However, these results are the product of inertia, rather than considered reflection. It is desirable to approach the regulation of a new practice such as CF from a functional perspective. This entails asking, first, what the practice seeks to achieve; and second, how regulation can improve it. ${ }^{121}$ The juxtaposition of securities and consumer law across the practice of CF permits us to evaluate the comparative efficacy of the regulatory tools used in these two domains.

\section{B When is mandatory disclosure useful?}

Mandatory disclosure is a cornerstone regulatory strategy in both securities and consumer laws, where it is often justified as a means of overcoming information asymmetry. ${ }^{122}$ However, a body of recent behavioural research makes clear that the context of disclosure matters greatly for its efficacy in improving outcomes for the recipients of information. ${ }^{123}$ What matters is not

\footnotetext{
${ }^{121}$ For our application of this approach in other contexts, see Kraakman et al, n 36 above, Ch 1; Armour et al, n 18 above, Ch 3.

${ }^{122}$ See eg ibid, Ch 8 and 10.

${ }^{123}$ There is a wide literature. For surveys, see O. Ben-Shahar and C.E. Schneider, More Than You Wanted to Know (Princeton, NJ: Princeton UP, 2014), 68-9 and Armour et al, n 18 above, 207-212. See also O. Bar-Gill, Seduction by Contract: Law, Economics and Psychology in Consumer Markets (Oxford: OUP, 2012), Ch 1; I. Ayres and A. Schwartz, ‘The No-Reading Problem in Consumer Contract Law’ (2014) 66 Stanf L Rev 545.
} 
so much whether disclosure is required, but rather what must be disclosed and how it must be conveyed. It is costly for most individuals to make sense of, and process, a large body of information: the simple fact of 'disclosure' does not equate to comprehension by the recipient. Indeed, the less sophisticated the individual, the greater the cost of comprehension. The problem of 'comprehension cost' is compounded by a common decision-making bias that leads individuals to over-estimate costs and benefits that are to be incurred immediately, as opposed to at some point in the future. ${ }^{124}$ This bias can lead people to defer indefinitely engagement with disclosures that they perceive will cost them time to comprehend. ${ }^{125}$

The implication of these findings is that to be effective, disclosures must be designed with considerable sensitivity to the context. Simply mandating the disclosure of large amounts of information does little, if anything, to improve consumers' decision-making if it is beyond their ability to comprehend. And, as such, disclosures are costly to produce. Ben-Shahar and Schneider argue that in many circumstances the exercise is 'worse than useless'. ${ }^{126}$ There are, however, circumstances in the context of both securities markets and consumer transactions in

\footnotetext{
${ }^{124}$ Individuals who exhibit this bias behave as if they discount the value of things happening in the future (and as between different times in the future) at a dramatically higher rate than those occurring immediately. They are said by economists to exhibit a 'hyperbolic' discount function: see G. Ainslie, 'Specious Reward: A Behavioural Theory of Impulsiveness and Impulse Control' (1975) 82 Psychological Bulletin 463; R.H. Thaler, 'Some Empirical Evidence on Dynamic Inconsistency' (1981) 8 Econ Lett 201; D Laibson, 'Golden Eggs and Hyperbolic Discounting' (1997) 112 QJE 443. This bias is not simply a behavioural phenomenon, but appears to have neurological foundations, as different parts of the brain are triggered in relation to decisions involving short-term rewards than for those assessing longer term options: See S.M. McClure, D.I. Laibson, G. Loewenstein and J.D. Cohen, 'Separate Neural Systems Value Immediate and Delayed Monetary Rewards' (2004) 306 Science 503; S.M. McClure, K.M. Ericson, D.I. Laibson, G. Loewenstein and J.D. Cohen, ' Time Discounting for Primary Rewards' (2007) 27 Journal of Neuroscience 5796.

125 See Armour et al, n 18 above, 210.

${ }^{126}$ Ben-Shahar and Schneider, n 123 above.
} 
which mandating disclosure can demonstrably improve outcomes. We shall consider whether these are relevant for CF.

\section{B Securities markets and mandatory disclosure}

As we have seen, the question of whether to require CF issuers to make extensive financial and other disclosures, similar to issuers in regulated securities markets, marks the biggest difference between US and UK regulation of equity CF. Although such information is too extensive to be read or analysed by the vast majority of retail investors, sophisticated professional investors do process and use it. Having large amounts at stake, it is rational for professional investors to invest time in analysing pertinent information. Moreover, such investors are typically selected, trained, and remunerated so as to minimise decisional biases. ${ }^{127}$

That disclosed information benefits sophisticated investors does not itself justify mandating such disclosure. Indeed, precisely because such investors can ask questions for themselves, disclosure is generally not mandated for financial products exclusively marketed to them. ${ }^{128}$ However, in regulated securities markets, the benefits of disclosure go beyond just the sophisticated investors who analyse the information. The market price moves in response to their trading activity, and thereby comes to reflect all publicly available information. ${ }^{129}$

\footnotetext{
${ }^{127}$ See eg Z. Shapira and I. Venezia, 'Patterns of Behaviour of Professionally Managed and Independent Investors' (2001) 25 J Bank \& Fin 1573; L. Feng and M.S. Seasholes, 'Do Investor Sophistication and Trading Experience Eliminate Behavioural Biases in Financial Markets?' (2005) 9 Rev Fin 305.

${ }^{128}$ See Armour et al, n 18 above, 223-225.

${ }^{129}$ See eg Z. Goshen and G. Parchomovsky, 'The Essential Role of Securities Regulation' (2006) 55 Duke LJ 711.
} 
Retail investors are thereby indirectly benefited by disclosure: they trade at the same price as if they had read the information. ${ }^{130}$

This makes mandatory disclosure easier to justify as a tool to protect retail investors. ${ }^{131}$ Yet, things look different in the case of equity CF: here, market mechanisms do not operate to aggregate information from sophisticated investors’ decisions into prices. As we saw earlier, equity CF offerings involve investors deciding sequentially about whether to invest at a price that does not change over the period of the offer. Subsequent investors receive only a very limited signal: that earlier investors (if any) chose to invest. This implies that the earlier investors thought the security was worth more than the price, but gives no indication of by how much, or how many other investors thought it was worth less than the price. A market in which the security traded would, in contrast, capture this sort of information. However, equity crowdfunders operate in a primary market with no information input from sophisticated traders. What is worse, herding-which our analysis suggests is likely in equity CF-implies that subsequent investors disregard any analysis of their own in favour of that implied by the investment decisions of earlier investors.

These features of the equity CF marketplace imply that disclosed information will only benefit retail investors if it happens to have been read and analysed by the earliest investors in an offer, and even then only to a very limited extent. In turn, this suggests that mandating

\footnotetext{
${ }^{130}$ See eg M.B. Fox, L.R. Glosten and G.V. Rauterberg, 'The New Stock Market: Sense and Nonsense' (2015) 65 Duke LJ 191, 221-225; Armour et al, n 18 above, 160-167.

${ }^{131} \mathrm{~A}$ full account of the extent to which a mandatory disclosure system is necessary to ensure that prices in regulated securities markets accurately reflect all available information inthe presence of market failures such as positive externalities and information asymmetries is beyond the scope of our current enquiry. See generally L. Enriques and S. Gilotta, 'Disclosure and Financial Market Regulation', in E. Ferran, N. Moloney and J. Payne (eds), The Oxford Handbook on Financial Regulation (Oxford: OUP, 2015), 520-525; Armour et al, n 18 above, 164-167.
} 
extensive disclosure of information by CF issuers-as is the case in the US-is likely to generate more costs than benefits. This is not to say that no disclosure is desirable for equity CF offers. Rather, the structure just described suggests that information about the identity of earlier investors may potentially be very useful for subsequent investors to determine the strength of the signal given by their support. Moreover, it also raises a more fundamental question, which we will address shortly, as to whether equity CF investment should be permitted at all, given such serious market flaws.

\section{B Consumers and structured disclosure}

Disclosure is also widely used as a regulatory strategy for consumer finance. In this context, because there is only a primary market between the consumer and the vendor firm, disclosures must be understood by the consumer to be effective. There has consequently been a recent shift in policy towards mandating the information provision in a manner that consumers can readily comprehend. ${ }^{132}$ Such 'structured' disclosure implies a very different style of information provision than the extensive disclosure statements mandated by securities law. ${ }^{133}$

The structured disclosure approach has much to commend it in theory. However, because of the highly contextual nature of the behavioural cues followed by unsophisticated investors, its success or otherwise is highly context-specific. ${ }^{134}$ An illustrative case study is

\footnotetext{
${ }^{132}$ See generally FCA, 'Applying Behavioural Economics at the Financial Conduct Authority', Occasional Paper No 1 (2013); J. Niemann, 'Behavioural Economics and the CFPB', Consumer Financial Protection Bureau Journal, 22 September 2015. See also Bar-Gill, n 123Error! Bookmark not defined. above, 32-41.

${ }^{133}$ See eg Armour et al, n 18 above, 256-261.

${ }^{134}$ The FCA's ongoing programme of field and laboratory experiments with different forms of structured disclosures provides numerous examples: see eg FCA, Stimulating Interest: Reminding Savers to Act When Rates Decrease, Occasional Paper No 7 (2015); FCA, Attention, Search and Switching: Evidence on Mandated
} 
Laibson et al's experiment on the impact of 'summary prospectuses' on retail investor decisionmaking as regards investment choices in mutual funds. ${ }^{135}$ In this context, investors choose to buy shares directly from the mutual fund, and so their decision is analogous to funders selecting equity CF pitches. The authors reported that summary prospectuses—which were intended to make the information easier for retail investors to digest—brought no measurable improvement in substantive choices. ${ }^{136}$ To be sure, there is evidence that changes to the way in which information is presented can have real effects on consumer behaviour. ${ }^{137}$ Yet, the lesson emerging from the experimental literature is that consumer-oriented disclosures cannot be effectively designed in the abstract; this must be done on the basis of evidence of actual consumer behaviour. For this reason, the UK's FCA has embarked on a programme of using behavioural economics experiments in the design of information regulation for consumer financial products. ${ }^{138}$

It may in principle be possible for structured disclosure to be beneficial to CF funders. For example, the FCA are considering introducing a mandatory 'risk warning' to be given to

Disclosure from the Savings Market, Occasional Paper No 19 (2016); FCA, Full Disclosure: A Round-up of FCA Research into Giving Information, Occasional Paper 23 (2016).

135 J. Beshears, J.J. Choi, D. Laibson and B.C. Madrian, 'How Does Simplified Disclosure Affect Individuals' Mutual Fund Choices?' in D.A. Wise (ed), Explorations in the Economics of Aging (Chicago: University of Chicago Press, 2011), 75.

${ }^{136}$ The substantive choices in both cases reflected an excessive focus on past returns and insufficient attention to fees, which would impair the investors' returns.

${ }^{137}$ M. Mercer, A.R. Palmiter and A.E. Taha, 'Worthless Warnings? Testing the Effectiveness of Disclaimers in Mutual Fund Advertisements' (2010) 7 J Emp Leg Stud 429 (SEC's mandated warning that 'past returns do not guarantee future performance' has no impact on retail investor decision-making; however, a more extensive warning— 'past returns usually do not persist'—did have an effect on investors' decisions).

138 See n 134 above. 
investors in equity CF, drawing attention to the high risk of losing their capital. ${ }^{139}$ If such risk warnings are shown to be efficacious, a similar message might also usefully be mandated in relation to reward CF, explaining the difference from an ordinary contract of sale. However, to avoid incurring compliance costs for no benefit, regulators should only pursue such steps on the basis of evidence as to efficacy.

\section{B Intervention beyond disclosure?}

Recent regulatory policy in consumer finance has emphasised that even structured disclosure is not always a solution to the problems of consumer decision-making, and that other-more interventionist—measures may sometimes be justified. ${ }^{140}$ Potential regulatory strategies range from—at the least interventionist—-the imposition of default rules beneficial to the consumer's position, through the imposition of mandatory rules to—at the most interventionist—outright prohibition of certain types of transaction. It is a simple insight that the more interventionist the regulatory technique, the greater the harm done if it is mis-specified. Inappropriately restricting a valuable practice can be just as harmful as failing to restrict an exploitative practice. The rapidly-growing body of experimental literature relating to consumer protection policy indicates, however, that successful regulatory interventions are often highly contextspecific. Considerable information must be gathered before an appropriate intervention can be designed.

Viewed from a consumer protection perspective, five features of CF offers are particularly salient. First, these are obviously very risky contracts for retail funders, who are also likely to be mistakenly optimistic about the prospects of particular firms, and consequently overinvest. Yet this in itself is not problematic. Provided funders can be restrained from risking

\footnotetext{
${ }^{139}$ FCA, Interim Feedback, n 7 above, 34.

140 See sources cited n 132 above.
} 
resources they cannot afford to lose, and are encouraged to diversify, exposure of this sort tracks investment risk generally. In this regard, limitations on the amount that retail investors may stake in equity CF, as employed in the UK, seem a particularly worthwhile policy.

Second, there appears to be little risk that consumer-funders' mistakes will be systematically exploited. A concern underpinning many consumer protection laws is that of 'imbalance' between the parties. A business firm usually enjoys economies of scale in designing the terms of a transaction, leading to advertising and standard terms designed to make the product appealing to consumers' biases. Market competition encourages firms to seek to take advantage of these errors as a way of selling more product. Quite apart from the unfairness of this dynamic, the prospect of such exploitation deters consumers from participating in markets, and the resources invested by firms in developing and marketing products that are not actually desired by consumers are wasted. However, in the context of CF, an entrepreneur is unlikely to be able to devote significant time to the design of a financing contract, and so is unlikely to be able to use this to exploit funders effectively. More plausibly, the portal may be able to capture economies of scale in the design of CF contracts. This implies that the focus of regulatory engagement should be vis-à-vis the portal rather than as between the entrepreneur and the funder. This is a component of equity CF regulation in both the UK and the US. However, UK consumer protection legislation-inappropriately in our viewfastens on the contract between entrepreneurs and reward CF funders.

Third, the problems of market failure appear greater in relation to equity than reward CF. The information needed to evaluate an equity investment is greater than for a purchase decision; the reward CF process actually reveals new information about consumer demand for the product; and herding problems are less in relation to reward than equity CF. This implies that - contrary to the regulatory pattern in the UK-the potential for regulation to improve market functioning may be lower in relation to reward than equity CF. 
Fourth, CF funding may be socially valuable despite market imperfections. This is most obvious with reward CF, where successful funding generates valuable information regarding the market for the firm's products. Even for equity CF, however, there may be valuable projects which, without this source of finance, would not get funded. ${ }^{141}$ Lack of hard assets may restrict access to debt finance; capital-raising on public markets is very expensive; and VC finance is geographically restricted — and involves a transfer of control that may be unpalatable to many entrepreneurs. ${ }^{142}$ Moreover, reward CF may be unsuitable for larger capital calls-beyond a certain scale, it may cannibalise the 'regular' market for the firm's product. ${ }^{143}$ Given these constraints on alternative funding sources, there is no reason to think that seeking equity CF should be construed as an adverse signal of a firm's quality. ${ }^{144}$ Regulation that makes this type of funding more difficult to raise may consequently have real social costs. It is therefore important to ensure that CF regulation actually serves to address extant market failures.

Fifth, while it may well be possible to design a more nuanced intervention that protects CF funders without restricting the practice itself, too little is currently known about how CF works for regulators to be able to select a policy instrument appropriately. There is consequently a risk of unnecessary restrictions being imposed. The way in which the UK's consumer protection regime imposes a mandatory cancellation option into reward CF contracts

\footnotetext{
${ }^{141}$ R. Nanda and M. Rhodes-Kropf, 'Financing Risk and Innovation' (2016) Management Science (advance publication).

${ }^{142}$ See, text to nn 16-17 above. See also J.M. Fried and M. Ganor, 'Agency Costs of Venture Capitalist Control in Startups' (2006) 81 NYU L Rev 967.

${ }^{143}$ Belleflamme et al, $\mathrm{n} 31$ above.

${ }^{144}$ Cf M.B. Dorff, 'The Siren Call of Equity Crowdfunding' (2015) 39 J Corp L 493, 496-497. For similar concerns with regard to pre-crowdfunding direct internet offerings in the 1990s see S.J. Choi, 'Gatekeepers and the Internet: Rethinking the Regulation of Small Business Capital Formation' (1998) 2 Journal of Small and Emerging Business Law 27, 38-39.
} 
appears to be a case in point. While intended to promote the interests of consumers, this provision seems entirely inappropriate for a context in which consumers undertake to share production risks with producers. Its consequence, it appears, is to restrict the raising of reward CF in the UK.

In the presence of a new practice such as $\mathrm{CF}$, there may be much for regulators to gain from undertaking to review the marketplace regularly but to postpone decisions about intervention. Repeat players in the market, such as portals, have incentives to introduce safeguards that increase investment returns, to the extent that this stimulates demand for offerings. Such incentives can be further sharpened by the implicit threat of regulatory intervention. Market-designed safeguards can consequently substitute for —or at the very least inform-regulatory intervention. As an example of this, we explore in the next section mechanisms introduced by portals in order to reduce the risk of investment in equity CF, where funders are most exposed and existing regulatory strategies (in the form of disclosure) seem ineffective.

\section{A Market-based safeguards for equity CF}

Where equity CF is permitted, market participants have experimented with mechanisms to reduce the risk that bad projects are funded and that investors become prey to fraudulent or opportunistic behaviour on the part of fundraisers. We divide these mechanisms into three categories: first, those that try to leverage more effectively the collective wisdom of the crowd, by reducing the possibility of inappropriate herding. Second, we consider the adaptation of contractual protection devices used by VCs and, to a lesser degree, angel investors. And third, we look at attempts to make equity CF make more use of customized versions of investor protection mechanisms used in traditional IPO markets. 


\section{B Leveraging the wisdom of crowds}

We have seen how the sequential arrival of investors in CF campaigns is prone to herding. ${ }^{145}$ This is driven by subsequent investors' inability to distinguish between prior investors who have positive information and those who have simply followed the herd. One way to mitigate this is to reveal more granular information about the attributes of (prior) investors. This makes it easier for non-expert investors to identify which of the already-committed investors are making investments on the basis of their own analysis of information, and which are simply drawing inferences from prior investors’ decisions.

A simple mechanism along these lines, commonly used in practice, is to let potential funders know not only the aggregate amount of funding pledged by prior investors, but also the individual distribution. The intuition is that the more a single investor pledges, the more careful her due diligence will have been. ${ }^{146}$ Even more nuanced inferences can be drawn if details of early investors' other interactions on the platform are made known to subsequent investors. This allows subsequent investors to draw inferences about the nature and quality of prior investors' expertise. For example, Appbackr, a US platform specialising in smart phone apps, makes available via user profiles information about investors' other on-platform investments and whether they have themselves launched an app. Kim and Viswanathan report that apps for which early backers have greater numbers of prior investments in the platformsignalling expertise in investing in the sector-or have themselves launched an app on the

\footnotetext{
${ }^{145}$ Above, text to nn 39-42.

${ }^{146}$ A study of German equity CF platforms finds that, where such information is made available, large investments by a single investor are positively correlated with the number of subsequent investments later the same day: L. Hornuf and A. Schwienbacher, ‘Funding Dynamics in Crowdinvesting’, Working Paper (2015), 18.
} 
platform—signalling expertise in app development—are more likely to be successful both in raising subsequent funding and, ultimately, as business ventures. ${ }^{147}$

Another-surprisingly powerful — tool is to facilitate what might be called 'crowd due diligence', ${ }^{148}$ through permitting would-be investors to pose questions to those seeking funding, the answers to which are then available to other potential investors. These Q\&A fora can reveal useful information not only about the merits of the project, but also the attitude of the entrepreneur and the expertise of the investors asking the questions. ${ }^{149}$ Expert investors' presence on such web fora helps less sophisticated investors to make more informed choices.

A more radical step to limit the risk of herding would be to allow access only to funders who can be expected to conduct some form of due diligence themselves before investing. A mild way of screening for this is to impose a minimum investment amount per individual—as, for example, the German platform Innovestment has done. ${ }^{150}$ More drastic, and somewhat counter to the very idea of CF, is the solution of limiting access to the platform only

\footnotetext{
${ }^{147}$ K. Kim and S. Viswanathan, “The "Experts” in the Crowd: The Role of "Expert” Investors in a Crowdfunding Market', working paper, City University of Hong Kong / University of Maryland (2016). Interestingly, the effect of early backers having development expertise is most significant for apps seeking funding at the pre-launch stage, where technical viability may not yet be clear, whereas the effect of their investment expertise is most significant at the post-launch stage. See also Vismara, n 44 above (on the UK equity CF platform Crowdcube the presence of early investors who consent to making their other investment choices public increases take-up of offers with subsequent investors).

${ }^{148}$ See Agrawal et al, n 56 above, 83-85.

${ }^{149}$ An example of such Q\&As section for a specific pitch can be found at http://tinyurl.com/185nxxl.

150 The minimum thresholds vary between $€ 500$ and $€ 25,000$ : see L. Hornuf and A. Schwienbacher, 'Should Securities Regulation Promote Crowdinvesting?’, working paper, SSRN (2015), 29-30.
} 
to expert investors. For example, AngelMD is a US investment platform which allows medical professionals to invest in medical start-ups. ${ }^{151}$

Finally, it may also be worth exploring mechanisms that seek to harness more clearly the analytic efforts of sophisticated investors for the benefit of retail investors. One such approach would be to designate a portion of an issue as available only to sophisticated investors, the funding decisions of which would then be clearly visible to retail investors, and more informative than simply an aggregated picture of all funding decisions. One might also imagine two-stage CF campaigns, in which in the first phase, only experts or experienced investors may invest, followed by the retail crowd once the experts have had the chance to signal.

\section{B Replicating sophisticated contractual protection}

Crowdfunders invest in companies that are at a similarly early stage of development to firms that raise VC or angel finance. But unlike VCs and angels, crowdfunders are unable to bargain for protection or to be meaningfully involved in the business so as to monitor the entrepreneur. However, equity CF platforms may play a role here. To start with, they may (and usually do) screen offerings themselves, much like individual members of angel investor pools do for the entire pool. ${ }^{152}$ That said, there is no evidence that platform screening is as reliable as an angel

\footnotetext{
${ }^{151}$ See https://www.angelmd.co/investor_faqs. The platform was established prior to the advent of retail equity CF in the US in May 2016, and so investors must also be 'accredited'-that is, wealthy (see n 68 above). Accredited investors without medical qualifications may also join on an invitation-only basis.

152 P. Belleflamme, N. Omrani and M. Peitz, 'The Economics of Crowdfunding Platforms' (2015) 33 Information Economics and Policy 11, 18.
} 
investor’s, because platforms’ incentives to do so can be weaker. They receive a fee if the pitch is successful, but do not usually have a financial stake in the fundraising companies' success. ${ }^{153}$

Because potential CF investors may be sceptical about a platform's ability or incentives to screen projects effectively, especially before the platform has established a reputation on the market, an alternative is to co-opt angel investors with an established track record to do the screening. For example, the UK platform SyndicateRoom, 'only list[s] companies that are already backed by professional "business angels", who are investing their own money and thus have taken an active role in evaluating the strength of the deal'. ${ }^{154}$ It then offers its members 'the "same share class and same price per share" if they decide to invest alongside these professionals'. ${ }^{155}$

Another technique is to seek to deploy the kinds of contractual governance mechanisms used by VCs and angel investors. Generally, CF deals do not employ such mechanisms, because of the high coordination costs faced by investors. ${ }^{156}$ The desire to reduce coordination costs can leave funders exposed to entrepreneur opportunism: some CF deals provide funders with securities that lack voting rights and are subordinated to entrepreneurs' equity claims, in sharp contrast with VCs' practice of taking outsize control rights and liquidation preference. ${ }^{157}$ Some platforms, however, consciously market themselves as protecting crowdfunders by acting as their nominee in negotiating — and making use of — the

\footnotetext{
153 ibid, 17.

154 https://www.syndicateroom.com/about-us/about-syndicateroom.aspx.

155 ibid.

156 See text to n 15 above.

${ }^{157}$ See L. Hornuf and A. Schwienbacher, 'Crowdinvesting - Angel Investing for the Masses', in H. Landström (ed), Handbook of Research on Venture Capital: Volume 3-Business Angels (Cheltenham: Edward Elgar, 2016), 381.
} 
typical contractual rights VCs reserve for themselves. For example, UK equity CF platform Seedrs makes a point of signing investment agreements in their capacity as crowdfunders' nominee. Such agreements grant investors pre-emption rights, tag-along rights, and negative control (veto rights) regarding important issues, 'such as the winding-up of the company, changing the business of the company, issuing preference shares, transferring assets out of the company, making certain loans, or increasing director salaries beyond an agreed level'. ${ }^{158}$ These rights are exercised by the platform on investors’ behalf. ${ }^{159}$

Similarly to angel investor syndicates, some continental European platforms, such as MyMicroInvest and Innovestment, ${ }^{160}$ use a special purpose vehicle to hold shares in the crowdfunded companies, while investors receive certificates in the vehicle. Others, like Seedrs, use a nominee structure, by which the platform has title over the funded companies shares and investors have beneficial ownership. ${ }^{161}$ In either case, coordination costs are reduced by having someone in charge of exercising funders' rights collectively. ${ }^{162}$

\section{B Adapting IPO market institutions}

As argued in section 2.3, equity CF investors' position is not unlike that of retail investors in an IPO, but with the additional risks stemming from the unavailability of the market (and legal)

\footnotetext{
${ }^{158}$ See K. Kerrigan, 'Protecting Small Investors in Equity Crowdfunding Rounds’, Seedrs Blog, 17 March 2014, at https://www.seedrs.com/learn/blog/investors/trends-insights/small-investors-equity-crowdfunding. 159 ibid.

${ }^{160}$ See https://www.mymicroinvest.com/en/about/transaction and https://www.innovestment.de/so-funktioniertdas-investieren/beteiligungsmodell/.

${ }^{161}$ See J. Lynn, 'It isn’t Nominal - Why a Nominee Structure is Vital in Equity Crowdfunding', Seedrs Blog, 4 February 2013, at https://www.seedrs.com/learn/blog/entrepreneurs/tips-tricks/nominee-structure-equitycrowdfunding.

162 Of course, this itself introduces a further layer of potential agency costs.
} 
institutions that have developed through the decades to protect the latter. This provokes consideration of the extent to which such institutions could be adapted to the equity CF context.

Gatekeepers and disclosure. IPO markets have long relied on gatekeepers to reduce the risk that investors are ripped off: underwriters, audit firms, lawyers, analysts, and the stock exchange lend their reputations to the issuer and, each in their own way, vouch for its quality. ${ }^{163}$ This means that, having agreed to assist in the IPO, gatekeepers have incentives to ensure that the issuer's quality is no lower than the public perceives it to be. ${ }^{164}$ Could gatekeepers play a role similar in equity CF offers?

The obvious candidate would be CF platforms. In the long run, platforms' business model is only viable to the extent that investors trust that the fundraisers using them are reliable. Clearly, platforms cannot tolerate a record of fraud, fundraisers' opportunistic behaviour, or even poor business projects. Some form of screening is therefore to be expected. In fact, most platforms positively market themselves as undertaking some 'due diligence' on the fundraisers and their pitch—that is, investigating the veracity of claims made. ${ }^{165}$

\footnotetext{
${ }^{163}$ See generally Armour et al, n 18 above, 118-125.

${ }^{164}$ See eg S.J. Choi and A.C. Pritchard, Securities Regulation: Cases and Analysis, $3^{\text {rd }}$ ed (New York: Foundation Press, 2012), 702.

${ }^{165}$ For instance, Crowdcube asserts:

'As a platform approved and regulated by the Financial Conduct Authority, we review and approve every pitch on the site to ensure that all the information presented to the crowd is fair, clear and not misleading. We conduct thorough due diligence on the company, its legal structure, financials and directors using leading third-party providers such as Creditsafe, Experian and Onfido. We also verify evidence supporting any claims being made by the business such as market size, contracts and partnerships to ensure the information provided is accurate. This process can take between 3-4 weeks, sometimes longer if the company or raise is complicated..'

See Crowdcube, FAQs, at https://help.crowdcube.com/hc/en-us/articles/206234044-What-is-Crowdcube-sequity-crowdfunding-due-diligence-process-.
} 
One may wonder whether platform-mandated disclosures may serve investors as well as mandatory disclosures do in the IPO context. Generally speaking, an optimistic view would be that platforms will require disclosure of all essential items for potential investors, and possibly learn from the interactions between potential investors and issuers that occur on their websites to fine-tune required disclosures by including items that such interactions reveal to be valuable to investors.

Given the competition in the CF platforms market, however, a sceptic may take the view that platforms will impose less disclosure than investors would want, so as not to lose fundraising entrepreneurs to less demanding rivals. But loose standards will hurt the platform's reputation vis-à-vis investors: pleasing entrepreneurs from this perspective is definitely not in the long-term interest of the platform. Once again, with the industry in its infancy and hype about $\mathrm{CF}$, there is a serious risk that some of the current players in the market are there to make a quick buck and run.

As hinted before, Q\&A interactions between the crowd and the entrepreneur may unearth essential information. But investors should have a preference for platforms already requiring issuers to provide such information. In addition to relying on Q\&A sections to supplement disclosure on a case-by-case basis, platforms can save potential investors' time by coming up with standardized questions for entrepreneurs that they may be required to answer should a given number of platform users find them of relevance. ${ }^{166}$ It would be then easy to incorporate the regularly popular questions among the standard required disclosures, possibly on an industry by industry basis.

\footnotetext{
166 S. Hanks, G. Romano and E. Tonelli, 'Madness of Crowds or Regulatory Preconception?: The Weak Foundation of Financial Crowdfunding Regulation in the US and Italy' (2014) 11 Eur Co Law 243, 257.
} 
Pricing. The second principal tool of investor protection is the pricing mechanism itself. Section 2.3 briefly contrasted the bookbuilding process in the IPO market with fundraisers' home-made pricing on CF portals. This is another area where market innovation is generating tools to protect investors, in this case by lowering the risk of unrealistic valuations of fundraisers’ businesses.

Various platforms have devised arrangements aimed at improving the largely predominant home-made take-it-or-leave-it pricing model. Innovestment, a German CF platform, at one time used a multi-stage auction system to determine the offering price, ${ }^{167}$ but later abandoned it, due to investors' dissatisfaction with its complexity. ${ }^{168}$

To our knowledge, in only one case-German platform Bergfürst—has there been a serious attempt to establish a secondary market in CF shares offered on a platform. Although Bergfürst has been active since 2012, it has only managed to have two companies traded on its market, suggesting that this is not a viable model for most equity-crowdfunded firms. ${ }^{169}$ The reasons for that appear to be two-fold. Firstly, equity CF offerings are often too small, and buyers too few, for a liquid market to develop. Secondly, many EU regulations, such as the Market Abuse Regulation, now apply to both regulated markets and multilateral trading

\footnotetext{
${ }^{167}$ See Hornuf and Schwienbacher, n 146 above, 7, for a description of the auction process.

${ }^{168}$ Some investors did not understand how the process worked, and others did not like being left with no shares when bidding too low: phone conversation with Christine Friedrich, Managing Director of Innovestment GmbH (March 10, 2015).

${ }^{169}$ See https://de.bergfuerst.com/investitionsmoeglichkeiten/unternehmen (other investments available for trade on Bergfürst's platform are debt securities). Recently, though, Seedrs announced the launch of a secondary market for CF securities. See S. O’Hear, 'Equity crowdfunding platform Seedrs to launch secondary market', 7 May 2017, at https://techcrunch.com/2017/05/07/equity-crowdfunding-platform-seedrs-to-launch-secondary-market/. Notably, the pricing for individual trades would be made by Seedrs rather than left to investors' interactions.
} 
facilities, so that accepting to have one's shares listed on one of these (which seems to be a condition, however insufficient, to ensure liquidity) entails significant compliance costs.

\section{A Conclusion}

Crowdfunding by start-up firms is big news. The practice has grown astonishingly rapidly in the past few years, but there are big regional differences in the way in which it is being used. Equity CF, where funders buy minority shares in the business, has grown much more rapidly in the UK than the US. In contrast, the geographic pattern for reward CF, where funders are promised units of the firm's future product, has been the reverse of this: far more rapid growth in the US than the UK.

It seems hard to resist the conclusion that regulation has been one of the factors behind this pattern of development. In the US, equity CF for retail investors has until very recently been prohibited. Although they seek to facilitate this form of fundraising, reforms introduced under the JOBS Act still impose onerous disclosure obligations on firms. In contrast, the UK regime, while placing restrictions on the amount individual investors can stake in the asset class, imposes no prospectus requirement on founders, but rather requires their promotions to be 'fair, clear and not misleading'.

Turning to reward CF, the pattern of regulatory burdens is reversed. The UK's consumer protection laws-derived from the EU acquis - appear prone to upset risk-sharing arrangements in reward CF. Most notably, consumers enjoy non-waivable rights to cancel distance selling contracts after receipt of the goods, meaning that reward funders do not bear any risk that rewards will not meet with their expectations. In contrast, US consumer protection laws focus on policing fraud, misrepresentation, and breaches of agreed undertakings. 
While both forms of CF involve decisions being made by funders with very incomplete information, the interaction between funders yields effects that point in different directions. The promise of reward CF is that by committing funding, backers reveal their preferences regarding the proposed product, and a successful funding campaign thus generates new positive information about the viability of the project. In this respect, reward CF harnesses the 'wisdom of the crowd'. In contrast, the peril of equity CF is that funders making investment decisions in sequence are likely to 'herd' after early participants, such that the collective decision actually gets made on the basis of less information than the investors may have possessed at the beginning. This comparison of the functioning of the two funding markets suggests that regulatory scrutiny of equity CF should be comparatively more intensive than for reward CF: the opposite of the UK's current approach.

The inconsistencies in the treatment of CF stem from the application of pre-existing rules devised for different, albeit on their face formally similar phenomena, coupled with lawmakers' inertia. A functional approach to regulating $\mathrm{CF}$, focusing on the extent to which particular interventions improve outcomes, highlights the inappropriateness of many of the current tools employed by regulators. There is no basis for assuming that retail funders will benefit, however indirectly, from lengthy mandatory disclosures, given that CF takes place in a primary market characterised by the absence of a bookbuilding process or similar auction mechanism to aggregate information from sophisticated investors. That makes the expense of a detailed mandatory disclosure regime for CF offerings unjustified. Similarly, while there may be a case for more nuanced interventions designed to protect consumers' interests, there is insufficient evidence at this early stage of the market's development to know what such measures should look like, and inappropriate mandatory rules can easily do more harm than good. That said, one measure that clearly does appear useful is restricting the extent of retail 
investors' overall exposure to CF, as has been done in the UK and, less efficaciously, in the US.

CF platforms have incentives to implement measures to protect funders; these incentives are enhanced by the implicit threat of greater regulatory intervention. A review of the marketplace reveals a great deal of activity in this respect, with experimentation across a diversity of approaches. We argue that for the present, regulators are well advised to stand back and observe which of these experiments succeeds, and why. 